\title{
Mendelian cytogenetics. Chromosome rearrangements associated with mendelian disorders
}

\author{
Niels Tommerup
}

The first successful mapping of a mendelian disorder by chromosome rearrangements was that of the Duchenne muscular dystrophy locus to Xp21. ${ }^{1-5}$ Since then, chromosome aberrations which delete, truncate, or otherwise rearrange and mutate specific genes have not only helped in the mapping of other disease loci, ${ }^{6}$ but have turned out to be key elements for the rapid isolation of disease genes by positional cloning strategies. ${ }^{7}$ Accordingly, a listing of the clinical disorders in which associated chromosome rearrangements have been described forms a part of the Human Gene Mapping Workshops. ${ }^{6}$ Although the early success led to a proposal for systematic cytogenetic analysis of subjects with mendelian disorders, ${ }^{8}$ this has rarely been done. A common feeling is that, as mutations, these rearrangements are rare exceptions. The aim of the present review is to document that they may be rare, but are not exceptions, and to focus on factors which may influence their occurrence and facilitate their detection.

\section{Contiguous gene syndromes in relation to mendelian genetics}

Genetic disorders are usually classified into mendelian, chromosomal, and multifactorial categories. Mendelism involves transmission patterns of traits which traditionally are thought to be determined by single genes. The mere fact that a chromosome rearrangement may lead to the development of a mendelian disorder suggests that this distinction between mendelian and chromosome disorders may be arbitrary. ${ }^{9}$ This is illustrated by Miller-Dieker syndrome (MDCR), lissencephaly with a characteristic facial appearance, that was originally listed as an autosomal recessive condition owing to the presence of familial cases with two or more affected sibs. ${ }^{9}$ All familial cases analysed have so far been shown to be associated with unbalanced segregation of familial translocations or inversions, leading to segmental aneuploidy (deletion) of a distal segment of $17 \mathrm{p} .{ }^{10-12}$ Thus, MDCR not associated with a chromosome abnormality is probably best explained as an autosomal dominant condition where all mutations are de novo.

MDCR also illustrates a mutational mechanism that may eventually explain a sub- stantial part of the heterogeneity and overlap in syndromology: contiguous gene syndromes where microscopic or submicroscopic deletions (or duplications) involve an array of closely positioned genes. ${ }^{1314} \mathrm{~A}$ purpose of the molecular characterisation of contiguous gene syndromes is to identify individual genes responsible for specific components of the phenotypic complex. This is probably best illustrated by the molecular studies of deletions and translocations involving $11 \mathrm{p} 13$ associated with various combinations of Wilms's tumour, aniridia, genitourinary malformations, and mental retardation (WAGR complex). ${ }^{15}$ The resulting isolation of candidate genes for Wilms's tumour (WT1) ${ }^{1617}$ and aniridia (AN2, PAX6) ${ }^{18} 19$ now provides a means for molecular studies and delineation of monogenic conditions within $11 \mathrm{p} 13 .{ }^{20-24} \mathrm{Simi}-$ larly, the dissection of the phenotype in MDCR has begun with the demonstration of submicroscopic deletions in cases with isolated lissencephaly..$^{25} 26$

Any visible chromosome imbalance almost invariably represents a contiguous gene disorder, but few chromosomal syndromes include features of sufficient specificity to permit a correlation with a recognised mendelian disorder. This includes many of the classical chromosome disorders, ${ }^{27}$ as well as newly recognised ones. ${ }^{28}$ Although these chromosome aberrations may not have immediate implications for known mendelian traits, future molecular dissection of these disorders may change this.

\section{Chromosome rearrangements in relation to autosomal dominant, autosomal recessive, and $\mathrm{X}$ linked disease}

Specific chromosome rearrangements have predominantly been described in autosomal dominant (AD) and in X linked conditions. Of the 625 chromosomally mapped loci associated with genetic disorders, $54(8.6 \%)$ are $\mathrm{X}$ linked. ${ }^{29}$ However, more than one third of the approximately 70 mendelian disorders associated with a specific chromosome rearrangement are $\mathrm{X}$ linked ${ }^{6}$ (figure). This excess can be explained by almost routine application of cytogenetic analysis in two particular groups of 


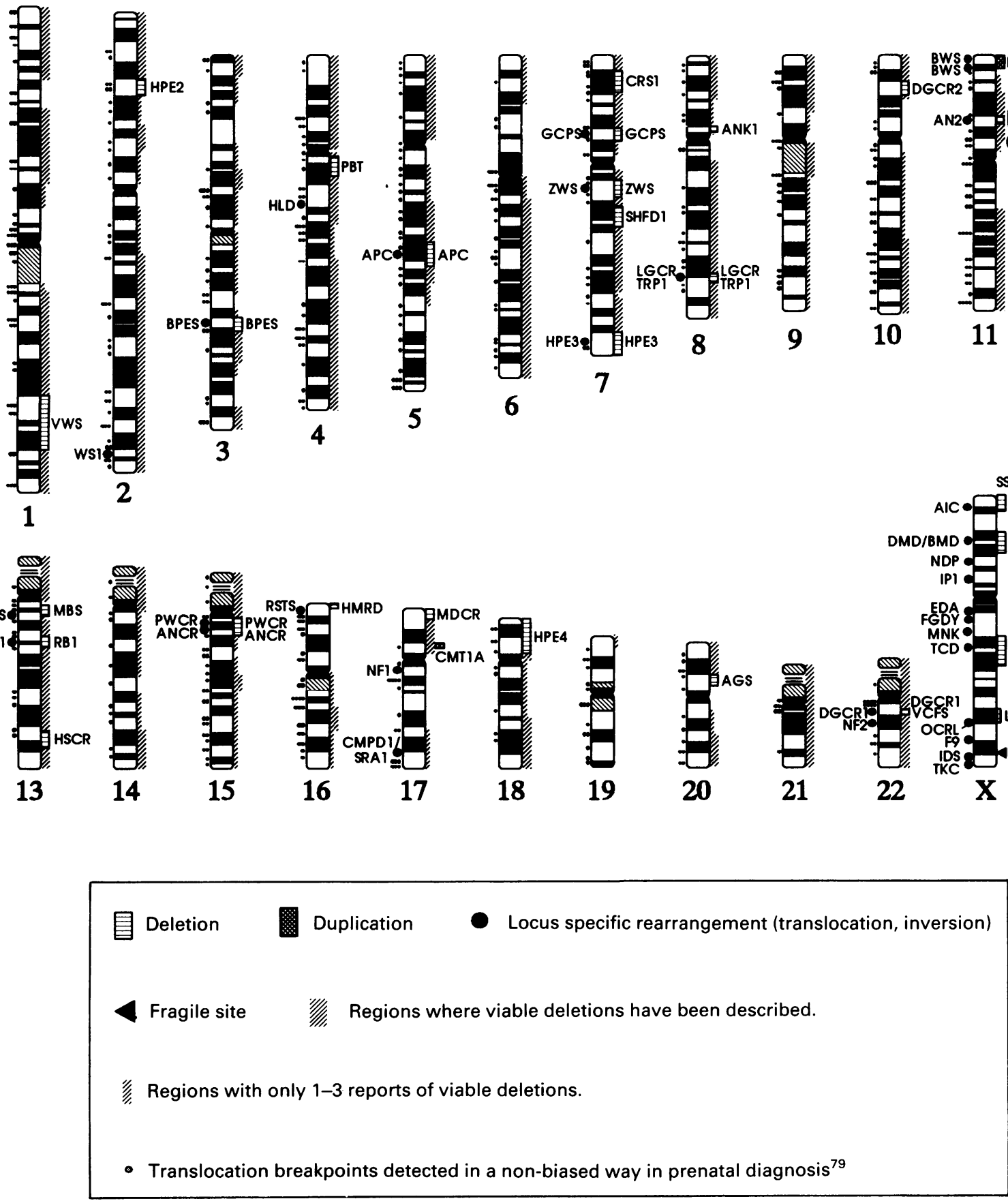

Localisation of mendelian disorders where chromosome rearrangements have been described. For explanation of symbols, see Appendix.

patients: females affected with $\mathrm{X}$ linked diseases, suggesting $\mathrm{X}$;autosome translocations, and males suffering from two or more $\mathrm{X}$ linked disorders, suggesting a contiguous gene syndrome. Since there are no a priori reasons to believe that chromosome rearrangements should be less frequent in $\mathrm{AD}$ than in $\mathrm{X}$ linked disorders, the underrepresentation in $\mathrm{AD}$ disorders is probably because of ascertainment bias.

The cytogenetic data in autosomal recessive (AR) disorders are so scanty that reliable statements regarding their frequency cannot be made. In only one AR disorder (Zellweger syndrome) has more than one chromosome rearrangement been described, a de novo deletion and a de novo inversion. ${ }^{3031} \mathrm{~A}$ specific chromosome mutation will only show an AR locus if the other allele happens to be mutated (unmasking of heterozygosity), ${ }^{32}$ and this will be a rare occurrence as the gene frequencies for even the most common AR disorders do not exceed $1 / 25$ to $1 / 50$. Owing to the number of recessive traits, and the relatively high frequency of familial translocations and inversions in man, ${ }^{33}$ some of these breakpoints may affect recessive loci. Thus, several murine balanced translocations are lethal in the homozygous state. ${ }^{34}$ The risk of unmasking of heterozygosity by a transmissible chromosome rearrangement will increase with the number of individuals that receive the rearrangement. In addition, familial translocations may predispose to the formation of uniparental 
Table 1 Chromosome rearrangements in deletion viable regions.

\begin{tabular}{|c|c|c|c|}
\hline \multirow{2}{*}{$\begin{array}{l}\text { Disorder } \\
\text { (locus symbol) }\end{array}$} & \multirow{2}{*}{$\begin{array}{l}\text { Chromosomal } \\
\text { localisation }\end{array}$} & \multicolumn{2}{|c|}{ Type of rearrangement } \\
\hline & & Deletions (No) & Locus specific type \\
\hline $\begin{array}{l}\text { AGS } \\
\text { AHC } \\
\text { AIC } \\
\text { AIED }\end{array}$ & $\begin{array}{l}20 \mathrm{p} 11.23-12.1 \\
\mathrm{Xp} 21 \\
\mathrm{Xp} 22.3 \\
\text { Xp21 }\end{array}$ & $\begin{array}{l}\text { Multiple } 178 \mathrm{~b} 179 \mathrm{a} \\
\text { Multiple } \\
\text { Multiple } 180 \mathrm{a} \\
\text { 180a }^{181 \mathrm{a}}\end{array}$ & $t(X ; 3)(p 22 ; q 12)^{182 a}$ \\
\hline $\begin{array}{l}\text { ANCR } \\
\text { AN2/PAX6 }\end{array}$ & $\begin{array}{l}15 \mathrm{q} 11-12 \\
11 \mathrm{p} 13\end{array}$ & $\begin{array}{l}\text { Multiple(mat) } \text { Mut }^{65-68 a, d 122 a ~ 183 a} \\
\text { Multiple }^{52 a, d} 54 d\end{array}$ & $\begin{array}{l}\text { inv(15)(p11q13)mat }{ }^{6869 b} \\
\mathrm{t}(4 ; 11)(\mathrm{q} 22 ; \mathrm{p} 13)^{60 \mathrm{~b}} \\
\mathrm{t}(11 ; 22)(\mathrm{p} 13 ; \mathrm{q} 12.2)^{58 \mathrm{~b}} \\
\mathrm{t}(5 ; 11)(\mathrm{q} 13.1 ; \mathrm{p} 13)^{59 b} \\
\mathrm{t}(5 ; 11)(\mathrm{q} 11 ; \mathrm{p} 13)^{284 a x}\end{array}$ \\
\hline ANK1 & $8 \mathrm{p} 11.1$ & $3^{187 a} 188 a$ 186c? & $\begin{array}{l}\mathrm{t}(8 ; 12)(\mathrm{p} 11 ; \mathrm{p} 13)^{184 b} \\
\mathrm{t}(3 ; 8)(\mathrm{p} 21 ; \mathrm{p} 11)^{185 \mathrm{~b}}\end{array}$ \\
\hline $\begin{array}{l}\text { APC } \\
\text { AZF }\end{array}$ & $\begin{array}{l}5 q 22 \\
Y q 11\end{array}$ & $\begin{array}{l}5^{189 a} \text { 191a 190b 183d } \\
\text { Multiple }{ }^{193-196 a}\end{array}$ & $\mathrm{t}(5 ; 10)(\mathrm{q} 22 ; ?)^{\mathrm{e}}$ \\
\hline BPES & $3 q 23$ & $4^{199 a} 172 d$ & $\begin{array}{l}\mathrm{t}(3 ; 11)(\mathrm{q} 21 ; \mathrm{q} 23)^{198 \mathrm{~b}} \\
\mathrm{t}(3 ; 4)(\mathrm{q} 23 ; \mathrm{p} 15.2)^{200 \mathrm{a}} \\
\mathrm{t}(3 ; 8)(\mathrm{q} 23 ; \mathrm{p} 21.1)^{197 a}\end{array}$ \\
\hline $\begin{array}{l}\text { CDPX1 } \\
\text { CRS1 }\end{array}$ & $\begin{array}{l}\mathrm{Xp} 22.3 \\
7 \mathrm{p} 21\end{array}$ & $\begin{array}{l}\text { Multiple }{ }^{70} \\
\text { Multiple }\end{array}$ & \\
\hline $\begin{array}{l}\text { CYBB } \\
\text { DFN3 }\end{array}$ & $\begin{array}{l}X p 21 \\
X q 21\end{array}$ & $\begin{array}{l}\text { Multiple } 72209210 a, b \\
\text { Multiple }^{37211}\end{array}$ & \\
\hline $\begin{array}{l}\text { DFN3 } \\
\text { DGCR1 }\end{array}$ & $\begin{array}{l}\mathrm{Xq} 21 \\
22 \mathrm{q} 11\end{array}$ & & \\
\hline $\begin{array}{l}\text { DGCR1 } \\
\text { DGCR2 }\end{array}$ & $10 \mathrm{p} 13$ & Multiple ${ }_{7^{214 a, d} 218 a}^{213-217 a, d}$ & $\mathrm{t}(2 ; 22)(\mathrm{q} 14.1 ; \mathrm{q} 11.1)^{212 b}$ \\
\hline $\begin{array}{l}\text { DMD/BMD } \\
\text { GCPS }\end{array}$ & $\begin{array}{l}\text { Xp21 } \\
7 \text { p13 }\end{array}$ & $\begin{array}{l}\text { Multiple }{ }^{71} \text { 72a,b } \\
3^{163 a} 164 a\end{array}$ & Multiple ${ }^{219 a}$ \\
\hline & & & $\begin{array}{l}\mathrm{t}(3 ; 7)(\mathrm{p} 21.1 \mathrm{p} 13)^{160 \mathrm{~b}} \\
\mathrm{t}(6 ; 7)(\mathrm{q} 27 ; \mathrm{p} 13)^{161 \mathrm{~b}} \\
\mathrm{t}(6 ; 7)(\mathrm{q} 12 ; \mathrm{p} 13)^{162}\end{array}$ \\
\hline $\begin{array}{l}\text { GK } \\
\text { HLD }\end{array}$ & $\begin{array}{l}X p 21 \\
4 q 12\end{array}$ & Multiple $^{71}$ 72a,b & $t(4: 5)(a 21: 015 \cdot 3)^{231 b}$ \\
\hline HMRD & $16 \mathrm{p} 13.3$ & $4^{88 \mathrm{a}, \mathrm{d}}$ & $\begin{array}{l}\mathrm{t}(4 ; 5)(\mathrm{q} 21 ; \mathrm{p} 15.3)^{232} \\
\mathrm{t}(4 ; 6)(\mathrm{q} 21 ; \mathrm{p} 24)^{232 b}\end{array}$ \\
\hline $\begin{array}{l}\text { HPE2 } \\
\text { HPE3 }\end{array}$ & $2 \mathrm{p} 21$ & $4^{233 a}$ & \\
\hline HPE4 & $\begin{array}{l}7 q 35 \\
18 p\end{array}$ & $\begin{array}{l}\text { Multiple } 234 \text { 236 237a,d } \\
\text { Multiple }\end{array}$ & $t(7 ; 9)(q 36 ; q 34)^{235 b}$ \\
\hline $\begin{array}{l}\text { HSCR } \\
\text { KAL1 }\end{array}$ & $13 \mathrm{q} 33.1$ & Multiple $3^{234-23 l_{a}}$ & \\
\hline $\begin{array}{l}\text { KAL1 } \\
\text { LGCR }\end{array}$ & $\begin{array}{l}\mathrm{Xp} 22.3 \\
8 \mathrm{q} 24.11\end{array}$ & Multiple ${ }^{70 a}$ & \\
\hline LGCR & $8 \mathrm{q} 24.11$ & Multiple 127244245 248a,d & $\begin{array}{l}\mathrm{t}(2 ; 8)(\mathrm{q} 33 ; \mathrm{q} 24.1)^{127} \\
\mathrm{t}(4 ; 8)(\mathrm{p} 15.3 ; \mathrm{q} 24.1)^{127} \\
\mathrm{t}(8 ; 11)(\mathrm{q} 24.11 ; \mathrm{p} 15.5)^{246} \\
\text { inv }(8)(\mathrm{q} 11.23 \mathrm{q} 21.1)^{247 \mathrm{~b}}\end{array}$ \\
\hline $\begin{array}{l}\text { LYP } \\
\text { MBS }\end{array}$ & $\begin{array}{l}\mathrm{Xq} 25 \\
13 \mathrm{q} 12.2\end{array}$ & $\begin{array}{l}1^{73 b} \\
1^{249 a}\end{array}$ & \\
\hline $\begin{array}{l}\text { MDCR } \\
\text { MRX2 }\end{array}$ & $\begin{array}{l}13 q 12.2 \\
17 \mathrm{p} 13\end{array}$ & Multiple ${ }^{10-122526 a, d}$ & $\mathrm{t}(1 ; 13)(\mathrm{p} 34 ; \mathrm{q} 13)^{250 b}$ \\
\hline $\begin{array}{l}\text { MRX2 } \\
\text { NF2 }\end{array}$ & $\begin{array}{l}\mathrm{Xp} 22.3 \\
22 \mathrm{q} 12.2 ?\end{array}$ & Multiple $^{70}$ & \\
\hline $\begin{array}{l}\text { NF2 } \\
\text { OA1 } \\
\text { PBT }\end{array}$ & $\begin{array}{l}22 \mathrm{q} 12.2 ? \\
\mathrm{Xp} 22.3\end{array}$ & Multiple? ${ }^{70}$ & $\mathrm{t}(4 ; 22)(\mathrm{q} 12 ; \mathrm{q} 12.2)^{254 b}$ \\
\hline $\begin{array}{l}\text { PBT } \\
\text { PWCR }\end{array}$ & $4 \mathrm{q} 12-13$ & $3^{257259260 \mathrm{a}}$ & $\mathrm{t}(4 ; 15)(\mathrm{q} 12 \mathrm{q} 21 ; \mathrm{q} 11)^{258 \mathrm{ax}}$ \\
\hline PWCR & $15 q 11-12$ & Multiple(pat) ${ }^{48-51 a, d}$ & $\begin{array}{l}\text { X;A translocation (see ref } 61)^{a} \\
5 \text { autosomal translocations } \\
\text { inv(15)(p13q13)pat }\end{array}$ \\
\hline RB1 & $13 q 14$ & 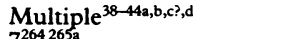 & Multiple ${ }^{41}$ \\
\hline SHFD1 & $7 q 11.2-21.3$ & $7^{264265 a}$ & $\begin{array}{l}\mathrm{t}(5 ; 7 ; 9)(\mathrm{q} 11.2 \mathrm{q} 34 ; \mathrm{q} 21.2 \mathrm{q} 31.3 ; \mathrm{q} 22.1)^{266 \mathrm{a}} \\
\mathrm{t}(7 ; 9)(\mathrm{q} 11.21 ; \mathrm{p} 12)^{263 \mathrm{~b}}\end{array}$ \\
\hline $\begin{array}{l}\text { SRY } \\
\text { SS } \\
\text { STS }\end{array}$ & $\begin{array}{l}\text { Yp12 } \\
\text { Xp22.3 } \\
\text { Xp22.3 }\end{array}$ & $\begin{array}{l}\text { Multiple }{ }^{70 a 267268 a} \\
\text { Multiple } \\
\text { Multiple } \\
\text { Moa }\end{array}$ & \\
\hline TCD & $\mathrm{Xq} 21$ & Multiple $^{37174 b 271 a, b}$ & $\begin{array}{l}\mathrm{t}(\mathrm{X} ; 7)(\mathrm{q} 21.2 ; \mathrm{p} 14)^{272 a} \\
\mathrm{t}(\mathrm{X} ; 13)(\mathrm{q} 21.2 ; \mathrm{p} 12)^{274 a}\end{array}$ \\
\hline TKC & $\mathrm{Xq} 28$ & & $\begin{array}{l}\mathrm{t}(\mathrm{X} ; 3)(\mathrm{q} 28 ; \mathrm{q} 21)^{275 a} \\
\mathrm{t}(\mathrm{X} ; 10)(\mathrm{q} 28 ; \mathrm{q} 11.2)^{275 a}\end{array}$ \\
\hline $\begin{array}{l}\text { TRP1 } \\
\text { VCFS } \\
\text { VWS }\end{array}$ & $\begin{array}{l}8 \mathrm{q} 24.11 \\
22 \mathrm{q} 11.2 \\
1 \mathrm{q} 32-41\end{array}$ & $\begin{array}{l}5^{276-280 a, c} \\
\text { Multiple } 282283 a, d \\
1^{285 a}\end{array}$ & $\operatorname{dir}$ ins $(8)(\mathrm{q} 24.11 \mathrm{q} 13.3 \mathrm{q} 21.13)^{281 \mathrm{~b}}$ \\
\hline WS1 & $2 q 35$ & & $\operatorname{inv}(2)(q 35 q 37.3)^{287 a}$ \\
\hline $\begin{array}{l}\text { WT1 } \\
\text { ZWS }\end{array}$ & $\begin{array}{l}11 \mathrm{p} 13 \\
7 \mathrm{q} 11.23\end{array}$ & Multiple & \\
\hline & 1411.23 & & $\operatorname{inv}(7)(\mathrm{p} 12 \mathrm{q} 11.23)^{31 \mathrm{a}}$ \\
\hline
\end{tabular}

See Appendix for explanation of locus symbols. $a=$ de novo aberration. $b=$ familial transmission. $c=$ evidence of germline mosaicism. $d=$ unbalanced familial reciprocal translocation/inversion. $e=$ Meera-Khan, personal communication. $x=v i s i b l y$ unbalanced translocation.

disomy, whereby AR mutations can be reduced to homozygosity. ${ }^{35}$ The occasional occurrence of an inherited balanced translocation or inversion would therefore not be unexpected in AR disorders. ${ }^{36}$

\section{The effect of chromosome localisation on types and frequencies of chromosome rearrangements}

Exact determination of frequencies of chromosome rearrangements in mendelian disorders can only be made by systematic studies of specific mendelian disorders. This has only been done in a few disorders, retinoblastoma (RB1) being the classical one. The results from RB1 may not necessarily be valid for other disorders, and one factor that will influence the frequency of chromosome rearrangements in a specific disorder is the chromosomal localisation of the corresponding gene.

Visible deletions among liveborns are absent or extremely rare for several regions of the human genome (figure), ${ }^{27}$ probably because they are incompatible with fetal survival. ${ }^{37}$ Whereas deletions are the most frequent type of rearrangement in those disorders which map to the 'deletion viable' regions (table 1, figure), visible deletions do not occur in liveborns affected with mendelian disorders mapping to the 'deletion non-viable' regions (table 2). The division of the genome into a deletion viable and non-viable part may have consequences not only for the type and fre- 
Table 2 Chromosome rearrangements in deletion non-viable* regions.

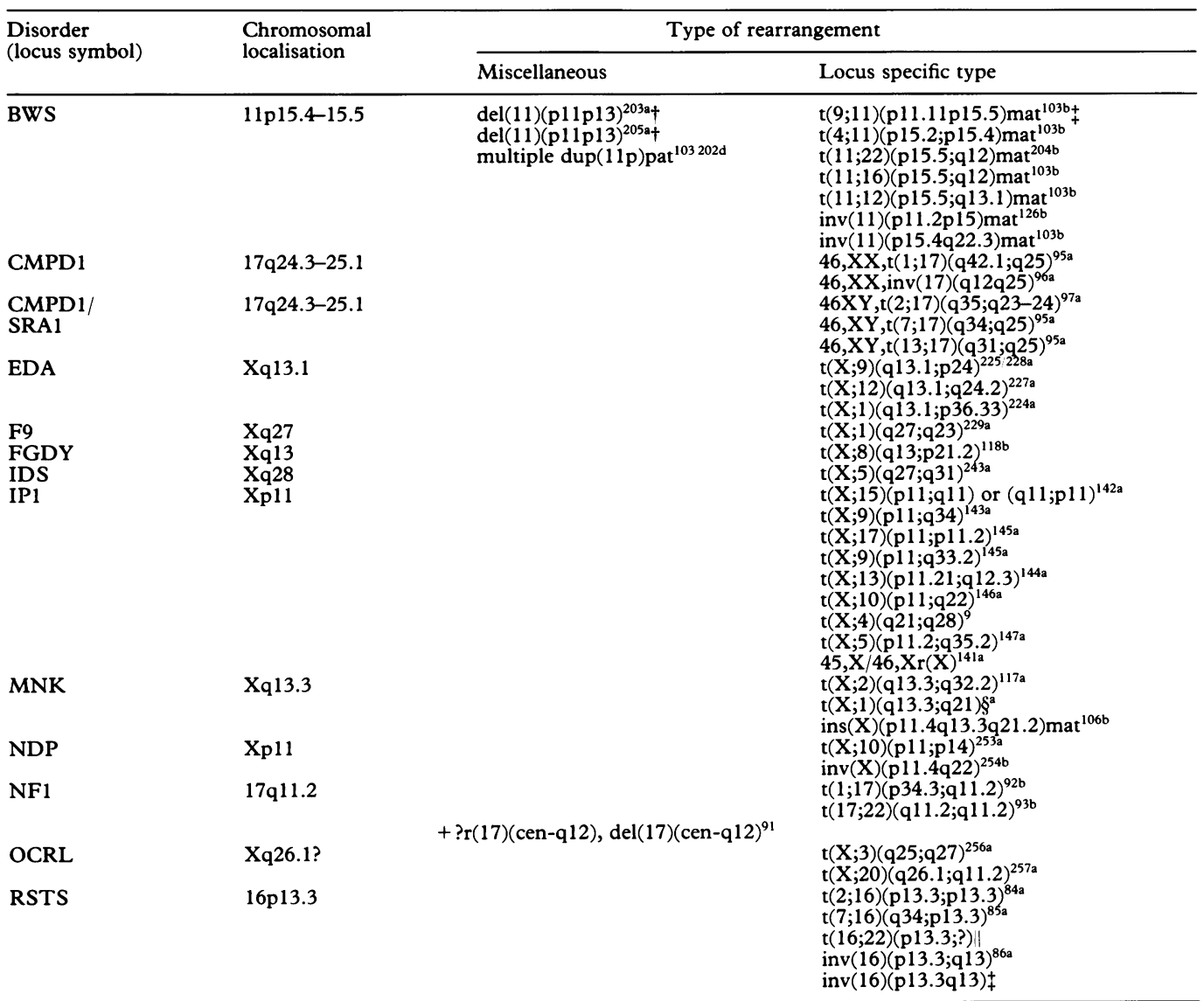

See Appendix for explanation of locus symbols. ${ }^{*}$ Including regions with only 1-3 reports of viable deletions. + Breakpoints not at established 11p15.4-.5 loci. ‡ Personal observation. § J Beck, personal communication. ||Cited in ref 87.

quency of rearrangements in mendelian disorders, but also for selection of strategies for their detection.

DISORDERS MAPPING TO REGIONS WHERE DELETIONS ARE VIABLE

Retinoblastoma, Wilms's tumour, and aniridia The early detection of cases with deletion of a D group (No 13) chromosome in association with retinoblastoma (RB1) ${ }^{38-40}$ led to extensive cytogenetic screening of large series of patients. $^{41-44}$ Consequently visible deletions have been found in 2 to $4 \%$ of all patients with RB1 when examined by metaphase technique, and in 4 to $8 \%$ of patients when examined by high resolution techniques. Reciprocal translocations have been detected in approximately $1 \%$ of patients in several independent surveys using both metaphase and prometaphase resolution, corresponding to $10 \%$ of the detected rearrangements. Thus, between 5 and $10 \%$ of all cases with RB1 have a visible chromosome mutation.

Larger systematic cytogenetic studies have not been reported in association with Wilms's tumour (WT1)/aniridia, so a direct comparison with the individual traits included in the Wilms's tumour/aniridia/genitourinary malformation/mental retardation (WAGR) complex cannot be made. However, in three large series of Wilms's tumour patients, altogether comprising 1335 cases, $^{45-47}$ aniridia was observed in 23 cases $(1 \cdot 7 \%)$. Furthermore, $1 / 3$ of aniridia cases are sporadic and, of these, $1 / 3$ develop Wilms's tumour. ${ }^{48} \mathrm{~A}$ visible deletion of $11 \mathrm{p} 13$ was seen in all 18 cases with combined WT1/aniridia in three high resolution cytogenetic surveys, ${ }^{47490}$ supporting the fact that most subjects with this combination have a visible deletion. All evidence supports a single map position for aniridia at $11 \mathrm{p} 13 .{ }^{51}$ If so, $1 / 3 \times 1 / 3(10 \%)$ of independent cases with aniridia may have a visible deletion. Since both traits are easily recognised, this is in line with the large number of cases with the WAGR complex and deletions of $11 \mathrm{p} 13$ that have been reported. ${ }^{52}$ As expected for contiguous gene syndromes, visible deletions and more complex rearrangements within $11 \mathrm{p} 13$ may not affect both loci. ${ }^{505354}$ The limited distance between WT1 and the candidate aniridia loci $(700 \text { to } 1000 \mathrm{~kb})^{1855}$ explains why a few persons with Wilms's tumour and aniridia have deletions below the limit of microscopic resolution.5556 Balanced chromosome rearrangements involving $11 \mathrm{p} 13$ have not been reported in association with Wilms's tumour, but one translocation with a breakpoint within the region has been seen in association with Potter syndrome, ${ }^{57}$ and three reciprocal translocations have been reported in familial aniridia. ${ }^{58-60}$ Taken together, the data are compatible with a frequency of chromosome rearrangements in all independent cases with WT1, aniridia, and WT1/aniridia in the same 
range as observed in $\mathrm{RB} 1$ ( 2 to $10 \%$ ), with deletions being by far the most frequent type of mutation.

Disorders associated with imprinting:

Prader-Willi and Angelman syndromes

Repeated observations of rearrangements involving chromosome 15 in patients with Prader-Willi syndrome (PWCR) led to numerous systematic studies. ${ }^{61-63}$ As a result, $60 \%$ of patients have been found to carry detectable chromosome 15 rearrangements, mostly deletions within 15q11-13 (table 1). The cytogenetic spectrum of 300 PWCR subjects with a chromosome 15 abnormality included 182 interstitial deletions, 34 unbalanced reciprocal translocations, 14 Robertsonian translocations, 16 small marker chromosomes, and four duplications, ${ }^{61-63}$ plus six balanced translocations and one pericentric inversion. ${ }^{61}$ The inversion was inherited from an unaffected father. ${ }^{64}$ Assuming that $60 \%$ of PWCR cases have a cytogenetic defect, the frequency of apparently balanced rearrangements thus appears to be close to that of $\mathrm{RB} 1(7 * 60 /$ $300)=1.4 \%$. However, it should be emphasised that balanced rearrangements were not reported among 358 PWCR patients studied in larger chromosome surveys in the period 1981 to 1991 . $^{61-63}$

Cytogenetic deletion of $15 q 11-13$ is also observed in 50 to $60 \%$ of subjects with Angelman syndrome (ANCR). ${ }^{65-68}$ Among the fewer than 100 cases with ANCR that have been studied so far, one apparently balanced rearrangement has been reported, a maternally inherited inversion with a breakpoint within $15 \mathrm{q} 13,{ }^{68}$ which was associated with a de novo submicroscopic deletion in the affected child. ${ }^{69}$

The frequency of visible deletions in RB1, PWCR, and ANCR thus varies considerably ( $\sim 5$ to $60 \%$ ), whereas the frequency of apparently balanced cytogenetic rearrangements may be within the same order of magnitude $(\sim 1 \%)$.

\section{$X$ linked disorders}

On the $\mathrm{X}$ chromosome, the male deletion viable regions involve $\mathrm{Xp} 22.3, \mathrm{Xp} 21, \mathrm{Xq} 21$, and Xq25 (figure). ${ }^{370-74}$ Owing to the excellent morbid anatomy of the $\mathrm{X}$ chromosome, ${ }^{29}$ these deletions are associated with recognisable mendelian traits, either as single gene disorders $^{73}$ or as part of contiguous gene syndromes. ${ }^{370-72}$ In a survey of five males with DMD and additional clinical signs suggesting a contiguous gene disorder, visible deletions were detected in all five cases. ${ }^{71}$ Bivariate flow karyotyping of 10 visible deletions within $\mathrm{Xp} 21$ associated with contiguous gene syndromes has provided a size estimate of these deletions in the range 4 to $14 \mathrm{Mb}^{72}$

The frequency of visible deletions in patients with single gene disorders mapping to $\mathrm{Xp} 21$ appears to be lower than observed in many autosomal disorders. In a systematic survey of 165 males with Duchenne or Becker muscular dystrophy only, no chromosome re- arrangements were observed. ${ }^{75}$ This may be somewhat surprising since submicroscopic deletions are extremely common in DMD, and since intragenic deletions in the $2.4 \mathrm{Mb}$ DMD locus might potentially reach the lower limit of microscopic resolution.

Disease associated deletions involving the distal part of Xp22.3 are seen in both males and females, in males associated with recessive traits and in females with dominant traits. ${ }^{70}$ Most other X chromosome deletions are preferentially inactivated in female carriers, either without phenotypic effects or associated with Turner symptoms, including gonadal dysgenesis or secondary amenorrhoea/premature menopause. ${ }^{76}$ However, deletion of the region $\mathrm{Xq} 27$ may result in preferential activity of the deleted X chromosome, ${ }^{77}$ and it has been suggested that this might be because of deletion of a locus which is involved in the normal $X$ inactivation process. ${ }^{78}$ If so, visible or submicroscopic deletions of $\mathrm{Xq} 27$ should be considered, along with $\mathrm{X}$; autosome translocations, in females affected with disorders mapping to this region.

\section{DISORDERS MAPPING TO REGIONS WHERE}

DELETIONS ARE NON-VIABLE

In contrast to deletions, breakpoints associated with constitutional autosome translocations detected in an unbiased way in large series of prenatal diagnoses ${ }^{79}$ (figure), as well as in reported $\mathrm{X}$;autosome translocations, ${ }^{8081}$ are distributed all over the genome. Hence, the presence of disease specific translocations would not be expected to be influenced by the chromosomal localisation of a disorder to the same extent as deletions. One modification of this is that the G-C rich chromosomal reverse $(\mathrm{R})$ bands contain many more genes than the A-T rich $G$ bands. ${ }^{8283}$ Therefore, disease specific breakpoints in translocations and inversions should predominantly be located in $R$ bands, which is indeed the case (figure).

If $\mathrm{RB} 1$ is the prototype of a clearly recognised disease localised within a chromosomal region where gross deletion is compatible with fetal survival, Rubinstein-Taybi syndrome (RSTS), von Recklinghausen neurofibromatosis (NF1), and, to some extent, campomelic dysplasia (CMPD1) exemplify disorders mapping to regions where deletions do not or only rarely occur.

\section{Rubinstein-Taybi syndrome, von Recklinghausen neurofibromatosis, and campomelic dysplasia}

A locus for RSTS has been assigned to $16 \mathrm{p} 13.3$ after the identification of several independent chromosome rearrangements with breakpoints within this region. ${ }^{84-87}$ Apart from small distal deletions associated with the haemoglobin $\mathrm{H} /$ mental retardation syndrome, ${ }^{88}$ viable visible deletions of $16 \mathrm{p} 13$ have not been described at all. ${ }^{278587}$ This, together with the detection of submicroscopic deletions in $25 \%$ of RSTS subjects with normal karyotypes, ${ }^{87}$ indicates that it is not deletions as such that do 
not occur or that are not compatible with the RSTS phenotype, but rather the size of the deletions.

Both RB1 and WT1 are tumour suppressor loci. ${ }^{89}$ However, it is unlikely that this feature in itself is associated with the high frequency of visible deletions seen in these disorders. Neurofibromatosis type 1 (NF1) also involves a tumour suppressor gene that maps to 17q11.2. ${ }^{6}$ The largest deletion which has so far been described in a patient with NF1 was $380 \mathrm{~kb}$ in size, ${ }^{90}$ well below the limit of microscopic resolution. This is in line with the general absence of reported constitutive deletions of this part of chromosome 17 (figure). ${ }^{27}$ In the only published case with a visible deletion of the proximal part of $17 \mathrm{q}$, the deleted segment was still present in most of the cells as a small ring chromosome. ${ }^{91}$ In contrast, and by analogy with the findings in RSTS, reciprocal translocations have been described in NF1 (table 2)..$^{9293}$

In campomelic dysplasia (CMPD1), chromosome analysis has been performed in a number of cases because of the frequent association with $46, \mathrm{XY}$ sex reversal (SRA1). ${ }^{94}$ Four de novo reciprocal translocations and one inversion, all involving 17q24-25, provide compelling evidence for the localisation of both CMPD1 and SRA1 to this region. ${ }^{95-97}$ Only a few viable deletions involving the distal part of $17 \mathrm{q}$ have been reported..$^{98-100}$ Thus, CMPD1 may illustrate a disorder mapping to a region where viable deletions do occur, but only rarely. Although CMPD1/SRA1 has been suggested to be a contiguous gene syndrome, ${ }^{95101}$ visible deletions have not been reported in patients with CMPD1/SRA1. Thus, the observed pattern of chromosome rearrangements in CMPDI resembles the pattern in disorders mapping to regions where deletions do not occur at all.

\section{Disorders associated with imprinting: \\ Beckwith-Wiedemann syndrome}

Genetic imprinting of one or more loci within $11 \mathrm{p} 15$ has been implicated in the aetiology of Beckwith-Wiedemann syndrome. ${ }^{102}{ }^{103}$ As in Prader-Willi syndrome, ${ }^{61} 104$ several different types of chromosome rearrangements have been encountered in BWS, including balanced rearrangements with breakpoints in the critical region of $11 \mathrm{p} 15$, exclusively of maternal origin, and duplications of the distal part of 11 p15, exclusively of paternal origin (table 2). It has been suggested that the duplications lead to excess expression of a paternally imprinted growth promoting gene within the region, such as insulin growth factor 2 (IGF2), whereas the balanced translocations might affect a maternally imprinted regulator within the region. ${ }^{103}$ Viable deletions involving the distal part of $11 \mathrm{p} 15$ have not been described, ${ }^{27}$ so it is not likely that such deletions will be seen in association with BWS either.

\section{$X$ linked disorders}

Menkes disease illustrates an $\mathrm{X}$ linked disorder which maps to an $\mathrm{R}$ band region (Xq13.3) where visible deletions have not been described in males. ${ }^{105} 106$ In a continuing cytogenetic survey of more than 200 unrelated males with Menkes disease, not a single case with a visible deletion has been detected. ${ }^{107}$

Although the proven $\mathrm{X}$ linked contiguous gene syndromes map to those regions where cytogenetic deletions are viable, $\mathrm{X}$ linked contiguous gene syndromes located within most $R$ band regions would be expected to be more numerous, considering the high gene density of $\mathrm{R}$ bands. However, these disorders will probably be associated with either submicroscopic rearrangements ${ }^{108}$ or with 'balanced' rearrangements which will lead to limited loss of material. The same argument applies to autosomal contiguous gene syndromes mapping to deletion non-viable regions.

So far, few mendelian disorders have been associated with visible duplications. ${ }^{103109}$ In general, duplications are better tolerated than deletions, ${ }^{27}$ so a smaller part of the genome will be duplication non-viable. However, it is reasonable to assume that for disorders associated with duplication of genetic material, the chromosomal localisation may also influence the occurrence of visible chromosome mutations.

\section{The effect of the parental origin of de novo chromosome rearrangements}

De novo chromosome rearrangements are predominantly of paternal origin, including all $\mathrm{X}$;autosome translocations examined so far. ${ }^{95}{ }^{110-116}$ This skewed parental origin has several implications for the detection of structural rearrangements in mendelian disorders.

\section{DE NOVO REARRANGEMENTS OF THE X CHROMOSOME}

As most chromosome rearrangements are paternal in origin, those involving the $\mathrm{X}$ must occur predominantly in females, where the phenotypic effect will be influenced by the $\mathrm{X}$ inactivation pattern. In balanced $X$;autosome translocations, where the translocation $\mathrm{X}$ is as a rule the active one, ${ }^{8081}$ truncation of a disease gene will lead to affected status in the female carrier. This mechanism is a main contributor to the disproportionately large number of $\mathrm{X}$ linked disorders where structural rearrangements have been described (figure). Since affected females with normal chromosomes are less likely to be reported, the actual frequency of $\mathrm{X}$;autosome translocations in affected females is unknown. The best estimate may come from Menkes disease (MNK), where diagnosis, including that of females, has been centralised to a few centres in the world. So far, two of six known MNK females are translocation carriers (J Beck, personal communication). ${ }^{107117}$

Males will only inherit an X;autosome translocation if the translocation does not lead to gonadal dysgenesis, a frequent finding in females with breakpoints on the $\mathrm{X}$ chromosome. ${ }^{76}$ In addition, an associated mendelian disorder in the mother will have to be suffi- 
ciently mild to allow reproduction. As a consequence, $\mathrm{X}$;autosome translocations are in general rare in males. ${ }^{80118}$ This, together with the presumed male non-viability of deletions involving the major part of the $\mathrm{X}$ chromosome (figure), led to the suggestion that intrachromosomal rearrangements, such as inversions and shifts, will be likely types of cytogenetic rearrangements in males affected with most $\mathrm{X}$ linked disorders. ${ }^{107}$ These rearrangements are probably very rare. ${ }^{119-121}$

\section{DISORDERS WHERE GENOMIC IMPRINTING IS INVOLVED}

As discussed previously, deletions involving almost the same region of 15q11-13 are frequently observed in both PWCR and ANCR. However, the deletion is always of paternal origin in PWCR ${ }^{61-63}$ and always of maternal origin in ANCR. ${ }^{122}$ Although the proportion of affected subjects carrying a cytogenetically visible deletion is the same in the two disorders, two significant aetiological factors support a higher frequency of PWCR than ANCR: (1) the large excess of maternal nondisjunction ${ }^{123}$ that may predispose to subsequent uniparental maternal disomy, as observed in PWCR, ${ }^{124} 125$ and (2) the presumed higher frequency of de novo rearrangements (deletions) of paternal origin which will also lead to PWCR.

In Beckwith-Wiedemann syndrome, all balanced rearrangements involving the distal part of $11 \mathrm{p} 15$ have been found to be inherited from the mother, similar to a preponderance of maternal transmission of BWS in non-cytogenetic familial cases. ${ }^{103126}$ Together with the predominantly paternal origin of de novo rearrangements, this implies that few if any de novo balanced rearrangements will be observed in subjects affected with BWS. In contrast, the mother may frequently carry the balanced rearrangement as a de novo rearrangement of paternal origin, or may have inherited the rearrangement from her father.

A similar sex dependent transmission pattern might be possible in balanced rearrangements associated with $\mathrm{ANCR}^{69}$ and PWCR, ${ }^{61} 64$ where the phenotypic effect of truncation or deletion ${ }^{69}$ will be influenced by the parental origin of the inherited rearrangement. ${ }^{68}$ Thus, apparently balanced rearrangements in PWCR should be of paternal origin, ${ }^{64}$ and of maternal origin in ANCR. ${ }^{69}$

It has now become an almost routine pro- cedure to search for the parental origin of chromosome rearrangements. Owing to the excess of de novo rearrangements of paternal origin, demonstration of a maternal origin of de novo rearrangements in a specific disorder will be much more significant with respect to a possible involvement of genomic imprinting ${ }^{122}$ than demonstration of a paternal origin..$^{95}$

\section{Mutational aspects with relevance for positional cloning ARE BREAKPOINTS IN BALANCED \\ REARRANGEMENTS LOCUS SPECIFIC?}

Although the majority of reciprocal translocations and inversions included in tables 1 and 2 are balanced at the cytogenetic level, a few of these have been shown to be associated with large submicroscopic deletions. ${ }^{127128}$ If this were a general feature, the assumption that these rearrangements involve single breaks within the target locus would be erroneous. ${ }^{93}$ However, of 23 apparently balanced rearrangements studied at the gene level, ${ }^{129-138} 22$ had breakpoints within the candidate gene locus (table 3). The assumed locus specificity of breakpoints in cytogenetically balanced rearrangements in mendelian disorders therefore seems justified, even though these rearrangements may not be truly conserved at the sequence level, since small deletions from a few bp to $<30 \mathrm{~kb}$ have been noted (table 3 ).

\section{LOCALISATION OF BREAKPOINTS OUTSIDE THE SPECIFIC TARGET}

Six unrelated reciprocal translocations have been reported in retinoblastoma patients, ${ }^{41}$ along with 14 specific reciprocal and eight insertional translocations. The odds therefore seem to favour a rearrangement as being disease specific. However, they also illustrate that the coincidental occurrence of a rearrangement is not uncommon. Further studies of the family, linkage studies in other families, search for similar published reports, and comparison with the clinical features associated with deletions or duplications of the regions involved are needed when considering the significance of a detected rearrangement.

Even if a structural chromosome mutation turns out to be the aetiological factor, some mutational mechanisms have been documented or suggested which may limit the utility of both balanced and unbalanced rearrangements for positional cloning, or at least provide

Table 3 Molecular details of assumed locus specific rearrangements.

\begin{tabular}{lcccc}
\hline $\begin{array}{l}\text { Disorder } \\
\text { locus symbol) }\end{array}$ & $\begin{array}{c}\text { No of studied } \\
\text { rearrangements }\end{array}$ & $\begin{array}{l}\text { No which truncate } \\
\text { the specific locus }\end{array}$ & $\begin{array}{c}\text { No with sequenced// } \\
\text { estimated deletion }\end{array}$ & $\begin{array}{l}\text { Size of } \\
\text { deletion }\end{array}$ \\
\hline DMD & 11 & $11^{129-132}$ & 2 & $71 / 72 \mathrm{bp}^{129}$ \\
GCPS & 3 & $2^{166}$ & & $5 \mathrm{~kb}^{132}$ \\
MNK & 2 & $2^{138251252}$ & \\
NF1 & 1 & $1^{135}$ & 1 & $<30 \mathrm{~kb}^{134}$ \\
RB1 & 4 & $4^{133134}$ & & \\
TCD & 1 & $1^{136}$ & & \\
Total & 1 & $1^{137}$ & & \\
\hline
\end{tabular}


conflicting data as to the disease or locus specificity.

\section{Spreading of $X$ inactivation in $X$;autosome translocations}

Although the majority of $\mathrm{X}$;autosome translocations associated with mendelian disorders have involved the $\mathrm{X}$ linked locus, it would be logical to assume that the autosomal breakpoint would occasionally represent the target. Most of the documented cases have been X;13 translocations associated with RB1. ${ }^{41139}$ At the cytogenetic level, 13q14 harbouring the RB1 locus seemed to be intact in all cases. The suggested mechanism for the development of $\mathrm{RB} 1$ in these cases is spreading of $\mathrm{X}$ inactivation into the autosomal segment including the RB1 locus. ${ }^{139}$ Inactivation of a putative locus at 9q32-34 by spreading of $\mathrm{X}$ inactivation has also been suggested in two X;autosome translocation carrying girls with incontinentia pigmenti or hypomelanosis of Ito. ${ }^{140}$

The paradox of incontinentia pigmenti (IP1 and IP2)

At least seven, possibly eight, ${ }^{9} \mathrm{X}$ chromosome rearrangements have been detected in sporadic cases of IP, with most of the breakpoints within Xp1 1. ${ }^{141-147} \mathrm{IP}$ is considered an X linked dominant disorder, which is lethal in males, and which only occurs in females as a result of the functional mosaicism associated with random lyonisation. The paradoxes of IP are as follows. (1) The locus for familial IP has been assigned to $\mathrm{Xq} 28$ by linkage analysis and not to Xp11. ${ }^{148149}$ Therefore, two loci associated with IP (IP1 and IP2) have been invoked. (2) It has been suggested that two, maybe three, of the translocation carriers ${ }^{143145}$ did not have IP but hypomelanosis of Ito (HI). ${ }^{140150} \mathrm{HI}$ has been considered the 'negative' of IP because the abnormal hypopigmented skin areas are distributed in the same pattern. The disorder may be a clinical manifestation of mosaicism or chimerism, as evidenced by the frequent association with chromosomal mosaicism involving a variety of different chromosomes. ${ }^{150} 151$ (3) Several different $\mathrm{X}$ chromosome breakpoints have been detected in the chromosomal rearrangements associated with IP. ${ }^{152-154}$ The distance between two distinct regions of breakpoints within Xp11, one close to the centromere and one more distal, is at least $2.5 \mathrm{Mb},{ }^{154}$ suggesting that if IP1 exists, the locus must be extremely large, or several loci within Xp11 may be involved. (4) Of two of the translocations stated to be associated with $\mathrm{HI}$, one maps to the distal region and one to the proximal region in Xp11.154

Considering the similar distribution of skin defects in IP and HI, the defect in these sporadic cases with IP may also involve somatic mosaicism, perhaps associated with $\mathrm{X}$ inactivation. One of the rearrangements involved a $\mathrm{r}(\mathrm{X}),{ }^{141}$ so dynamic mosaicism associated with ring chromosome instability might even be involved, ${ }^{155}$ in which case the gene(s) responsible for the pigmentary abnormalities might be situated anywhere on the $\mathrm{X}$ chromosome (for example, IP2 in Xq28). One implication of this would be that positional cloning of a putative IP1 locus defined by $\mathrm{X}$ chromosome breakpoints ${ }^{154}$ may be impossible.

Unmasking of mutations by rearrangement induced non-random $X$ inactivation

If the normal $X$ chromosome contains a mutated locus, non-random $\mathrm{X}$ inactivation of a structurally abnormal X chromosome may incidentally lead to clinically affected status of a female. ${ }^{156}$ The erroneous conclusion that the disease locus is regionally defined by the breakpoints of the rearrangement may be avoided by careful $\mathrm{X}$ inactivation studies. The possibility exists that this mechanism may be involved in IP1. It is uncertain whether a similar mechanism might be involved in two $\mathrm{X}$;autosome translocations with different breakpoints on Xp in Rett syndrome, ${ }^{157158}$ a disorder in which $\mathrm{X}$ linkage has been suggested by almost exclusive involvement of girls, but where linkage analysis seems to have excluded the $\mathrm{X}$ chromosome. ${ }^{159}$

Localisation of breakpoints close to but outside the open reading frame

The locus for Greig cephalopolysyndactyly (GCPS) has been pinpointed to $7 \mathrm{pl} 3$ by three balanced familial translocations, ${ }^{160-162}$ by deletions, ${ }^{163164}$ and by linkage studies. ${ }^{165}$ By the candidate gene approach, ${ }^{7}$ two of the three familial translocations were found to interrupt a zinc finger gene GLI3 located within $7 \mathrm{p} 13 .{ }^{166}$ However, the breakpoint in the third translocation occurred about $10 \mathrm{~kb}$ downstream of the $3^{\prime}$ end of GLI3. It was speculated that as a result a cis acting element was brought into the region of GLI3, thereby deregulating its expression. ${ }^{166}$

\section{Dynamic mosaicism associated with ring chromosomes}

Carriers of ring chromosomes harbouring tumour suppressor genes may be at increased risk of developing chromosome specific types of tumours, for example, $r(13)$ carriers may develop RB1, r(11) carriers WT1, r(22) carriers meningioma, etc. ${ }^{155}$ Conversely, the development of a specific type of tumour in a ring carrier may suggest that a tumour suppressor locus is located somewhere on that chromosome. Apart from the primary deletion associated with the formation of the ring, ring chromosomes are predisposed to secondary somatic rearrangements initiated by sister chromatid exchanges. The result may be fragmentation, gain or loss of ring material, including complete monosomy (dynamic mosaicism). A comparison between the localisation of the primary breakpoints and the likely tumour suppressor loci involved suggests that the secondary instability may be the most important factor predisposing to the development of tumours. ${ }^{155}$ Thus, unlike conventional constitutional deletions which can be used for the 
generation of disease related deletion maps, correlations between the primary ring associated deletions and phenotypic features should be regarded with caution.

Dynamic mosaicism may not be limited to the development of tumours, but should also be considered as a possible mechanism in the development of other disorders in ring carriers. One possible association is RussellSilver syndrome which shares many clinical features with ring chromosome 15 deficiencies. ${ }^{167}$

\section{Conclusions}

The present review has primarily been concerned with those rearrangements which can be expected to be encountered in a majority of mendelian disorders. Thus, the fragile site at Xq27 associated with the most common form of $\mathrm{X}$ linked mental retardation has not been discussed since it is so far the only fragile site known to be associated with a specific clinical entity.

Although deletions occur less frequently than reciprocal translocations in newborn screening series, ${ }^{33}$ any deletion of visible size will have a big chance of involving part or all of a gene. This may explain why viable deletions are the most frequent type of cytogenetic mutation in mendelian disorders. In contrast, a single breakpoint or a submicroscopic deletion associated with a translocation or inversion has to be more precisely located in order to involve a specific locus.

The majority of visible deletions associated with mendelian disorders has been observed in sporadic cases (tables 1 and 2). A few exceptions have been reported, which may be explained by the presence of mosaicism in a parental carrier, or a less severe phenotype associated with small deletions within certain regions, such as $13 \mathrm{q} 14$ associated with $\mathrm{RB} 1 .{ }^{41}$ In most other situations, the assumption that chromosomal deletions are reproductive lethal mutations is probably true. However, familial occurrence of deletions associated with mendelian disorders can be expected in two conditions: deletions involving the male deletion viable regions of the $\mathrm{X}$ chromosome, and familial translocations, especially insertional translocations. ${ }^{4154168-172}$

Apart from insertional translocations, other rare types of familial and sporadic rearrangements have been identified in association with mendelian disorders, in part during chromosomal surveys. ${ }^{91} 106$ As mentioned previously, intrachromosomal rearrangements, including shifts, may be the expected type of chromosome mutation in males affected with the majority of $\mathrm{X}$ linked diseases. ${ }^{107}$ Whether this apparent accumulation of otherwise rare types of rearrangement may reflect ascertainments which are different from those usually encountered in cytogenetics (prenatal diagnosis, MCA/MR, spontaneous abortions, etc) is at present unknown.

Without valid data derived from systematic cytogenetic surveys in the majority of disorders, the best estimate of a basic frequency of chromosome rearrangements in an autosomal dominant disorder is approximately $1 \%$, corresponding to the frequency of balanced translocations and inversions observed in RB1 (and maybe in PWCR and ANCR). If, in addition, visible deletions within the specific chromosome region are viable, this figure will be considerably higher.

The data favour that cytogenetic rearrangements will be present in a small, but not insignificant, fraction of subjects affected with many mapped and unmapped mendelian disorders. The detection of a chromosome mutation will have obvious counselling implications in the individual family. Considering the impact even a single specific rearrangement may have for gene mapping and cloning, a more systematic effort to detect these rearrangements should be pursued. In terms of value for rapid molecular isolation of the locus of interest, rearrangements involving locus specific breaks (for example, balanced translocations and inversions) will in general be the most valuable ones. Although the presence of additional congenital anomalies, other unexpected diseases, spontaneous abortions, stillbirths, etc, may suggest the involvement of a chromosome mutation in a patient or within a family, subjects with balanced rearrangements may not suffer from additional disorders. ${ }^{107}$ Furthermore, translocations and inversions may be both familial and de novo mutations (tables 1 and 2). Therefore, some of the most valuable mutations in terms of positional cloning may only be detected by systematic analysis.

If a reciprocal translocation is detected in a disorder that has not been mapped previously, the odds will favour a breakpoint within an $\mathrm{R}$ band being the specific one. In some cases this may ease subsequent attempts to confirm the specificity of new translocations, for example, by linkage mapping. Furthermore, for large scale screening programmes, high resolution chromosome analysis may be too cumbersome and time consuming. Screening strategies can be devised which in part will alleviate this. In disorders with a known chromosomal localisation, complete karyotyping by high resolution technique may not be needed. In disorders mapping to regions where deletions are unlikely to be viable, normal good quality metaphase technique may be sufficient to detect the single break rearrangements that can be expected. In addition, the deletion map shown in the figure may provide a basis for tentative exclusion mapping of mainly autosomal dominant disorders, where repeated chromosome analysis has failed to identify rearrangements. Such disorders might be expected to map within the deletion non-viable or less viable part of the genome. This was the case with two of the most recently mapped disorders, RSTS $^{85} 87$ and CMPD $1 .{ }^{95}$

Linkage mapping will be greatly eased by the rapidly increasing numbers of highly polymorphic microsatellites which can be analysed by the PCR technique. ${ }^{173}$ In this context a continuous registration and clinical follow up of subjects with known chromosome re- 
arrangements will become increasingly important. Whenever a disease has been mapped to a specific chromosome region, rapid reinvestigation of subjects carrying chromosome rearrangements within that region for key clinical features may provide essential mapping and clinical data. This approach was used successfully to detect choroideraemia ${ }^{174}$ in a patient with a previously reported $\mathrm{Xq} 21$ deletion, ${ }^{175}$ and to show reduced nerve conductance velocity in a patient with a large visible duplication encompassing the CMT1A locus on $17 \mathrm{p} .{ }^{109}$

The rapid construction of complete YAC and cosmid contigs ${ }^{176177}$ will greatly facilitate future mapping and isolation of specific disease breakpoints/genes, for example, in combination with in situ hybridisation techniques. The detection of rearrangements associated with mendelian diseases will therefore remain an important challenge for the clinical cytogeneticist. Many cytogenetic laboratories may be discouraged from systematic studies by the rarity of mendelian disorders and by the expectation of a relatively low frequency of associated cytogenetic rearrangements. As has been shown so convincingly in other fields of human genome mapping, concerted action would be the logical way to ensure a systematic detection of these highly valuable mutations in man.

This study was supported by the Danish Cancer Society (89-059, 90-021), the Norwegian Cancer Society, the Danish Medical Research Council (12-9292, 12-9744, 12-7414, 5.17-.4.2.53), The Foundation of 1870, and the Danish Biotechnology Research and Development Programme 1991-95 (5.18.03).

1 Greenstein RM, Reardon MP, Chan TS. An X-autosome translocation in a girl with Duchenne muscular dystrophy (DMD): evidence for DMD gene location. Pediatr Res 1977;11:457.

2 Verellen C, Markovic V, DeMeyer R, et al. Expression of an $\mathrm{X}$-linked recessive disease in a female due to nonrandom inactivation of the $\mathrm{X}$ chromosome. Am $\mathcal{F}$ Hum Genet 1978;30:97A.

3 Canki CT, Dutrillaux B, Tivadar I. Dystrophie musculaire de Duchenne chez une petite fille porteuse d'une translocation $\mathrm{t}(\mathrm{X} ; 3)(\mathrm{p} 21 ; \mathrm{q} 13)$ de novo. Ann Genet (Paris) 1979;22:35-9.

4 Lindenbaum RH, Clarke G, Patel C, et al. Muscular dystrophy in an $\mathrm{X} ; 1$ translocation female suggests that Duchenne locus is on $\mathrm{X}$ chromosome short arm. $\mathcal{F} \mathrm{Med}$ Genet 1979;16:389-92.

5 Jacobs PA, Hunt PA, Mayer M, Bart RD. Duchenn muscular dystrophy (DMD) in a female with an $\mathrm{X}$ autosome translocation: further evidence that the DMD locus is at Xp21. Am F Hum Genet 1981;33:513-18.

6 Frézal J, Schinzel A. Report of the committee on clinical disorders and chromosomal deletion syndrom

7 Collins FS. Positional cloning: let's not call it reverse anymore. Nature Genet 1992;1:3-6.

8 anymore. Nature Genet $1992 ; 1: 3-6$. disorders. Lancet 1982;i:322-3.

9 McKusick VA. Mendelian inheritance in man. Catalogs of autosomal dominant, autosomal recessive, and X-linked autosomal dominant, autosomal recessive, and X-linked phenotypes. 10th

10 Stratton R, Dobyns WB, Airhart SD, Ledbetter DH. New (t) chromosomal syndrome: Miller-Dieker syndrome

11 Gonosomy 17p13. Hum Genet 1984;67: 9 et al. Familial Miller-Dieker syndrome associated with pericentric Miller-Dieker syndrome associated with pericentric inversion of

12 Kuwano A, Ledbetter SA, Dobyns WB, Emanuel BS Ledbetter DH. Detection of deletions and cryptic translocations in Miller-Dieker syndrome by in situ hybridization. Am f Hum Genet 1991;49:707-14.

13 Schmickel RD. Contiguous gene syndromes: a componen of recognizable syndromes. F Pediatr 1986;109:231-41.

14 Emanuel BS. Molecular cytogenetics: toward dissection of the contiguous gene syndromes. Am $\mathcal{f}$ Hum Genet $1988 ; 43: 575-8$
15 Rose EA, Glaser T, Jones C, et al. Complete physical map of the WAGR region of $11 \mathrm{p} 13$ localizes a candidate Wilms' tumor gene. Cell 1990;60:405-8.

16 Call $\mathrm{KM}$, Glaser T, Ito $\mathrm{CY}$, et al. Isolation and characterization of a zinc finger polypeptide gene at the human chromosome 11 Wilms' tumor locus. Cell 1990;60:50920.

17 Gessler M, Poustka A, Cavenee W, et al. Homozygous deletion in Wilms' tumours of a zinc-finger gene identified by chromosome jumping. Nature 1990;343:774-8.

18 Gessler M, Simola KOJ, Bruns GAP. Cloning of breakpoints of a chromosome translocation identifies the AN2 pocus. Science 1989;244:1575-8.

19 Ton CCT, Hirvonen H, Miwa H, et al. Positional cloning and characterization of a paired box- and homeoboxcontaining gene from the aniridia region. Cell 1991;67:1059-74.

20 Haber DA, Buckler AJ, Glaser T, et al. An internal deletion within an 11 p13 zinc finger gene contributes to the development of Wilms' tumor. Cell 1990;61:1257-69.

21 Pelletier J, Bruening W, Li FP, et al. WT1 mutations contribute to abnormal genital system development and hereditary Wilms' tumour. Nature 1991;353:431-4.

22 Pelletier J, Bruening W, Kashtan CE, et al. Germline mutations in the Wilms' tumor suppressor gene are associated with abnormal urogenital development in Denys-Drash syndrome. Cell 1991;67:437-47.

23 Bruening W, Bardeesy N, Silverman BL, et al. Germline intronic and exonic mutations in the Wilms' tumour gene intronic and exonic mutations in the Wilms' tumour gene (WT1) affecting

24 Jordan T, Hanson I, Zaletayev D, et al. The human PAX6 gene is mutated in two patients with aniridia. Nature Genet 1992;1:328-32.

25 Ledbetter SA, Kuwano A, Dobyns WB, Ledbetter DH. Microdeletions of chromosome $17 \mathrm{p} 13$ as a cause of isolated lissencephaly. Am f Hum Genet 1992;50:182-9.

26 Dobyns WB, Elias ER, Newlin AC, Pagon RA, Ledbetter DH. Causal heterogeneity in isolated lissencephaly. Neurology 1992;42:1375-88.

27 Schinzel A. Catalogue of unbalanced chromosomal aberrations in man. Berlin: Walter deGruyter, 1984.

28 Smith ACM, McGavran L, Robinson J, et al. Interstitial deletion of (17)(p11.2p11.2) in nine patients. $A m \mathcal{F}$ Med Genet 1986;24:393-414.

29 McKusick VA, Amberger JS. The morbid anatomy of the human genome: chromosomal location of mutations causing disease. 7 Med Genet 1993;30:1-26.

30 Naritomi K, Hyakuna N, Suzuki Y, Orii T, Hirayama K. Zellweger syndrome and a microdeletion of the proximal long arm of chromosome 7. Hum Genet 1988;80:201-2.

31 Naritomi K, Izumikawa Y, Ohshiro S, et al. Gene assignment of Zellweger syndrome to $7 \mathrm{q} 11.23$ : report of the second case associated with a pericentric inversion of chromosome 7. Hum Genet 1989;84:79-80.

32 Bühler EM. Unmasking of heterozygosity by inherited balanced translocations. Implications for prenatal diabalanced translocations. Implications for prenatal dia-
gnosis and gene mapping. Ann Genet (Paris) gnosis and ${ }_{1983 ; 26: 133-7 .}$.

33 Hook EB, Hamerton JL. The frequency of chromosome abnormalities detected in consecutive newborn studiesdifferences between studies - results by sex and by severity of phenotypic involvement. In: Hook EB, Porter $\mathrm{IH}$, eds. Population cytogenetics. New York: Academic Press, 1977: 81-97.

34 Searle AG. Chromosomal variants. In: Lyon MF, Searle AG, eds. Genetic variants and strains of the laboratory mouse. 2nd ed. Oxford: Oxford University Press, 1989:582-616.

35 Pentao L, Lewis RA, Ledbetter DH, Patel PI, Lupski JR. Maternal uniparental isodisomy of chromosome 14: association with autosomal recessive rod monochromacy. $\mathrm{Am}$ fiation with autosomal recessive

36 Fannemel M, Riise R, Lofterød B, Tommerup N. Highresolution chromosome analysis in autosomal recessive disorders. Laurence-Moon-Bardet-BiedI syndrome. Clin Genet 1993;43:111-12.

37 Cremers FPM, van de Pol TJR, Wierenga B, et al. Molecular analysis of male-viable deletions and duplications allows ordering of $52 \mathrm{DNA}$ probes on proximal $\mathrm{Xq}$ Am ₹ Hum Genet 1988;43:452-61.

38 Lele KP, Penrose LS, Stallard HB. Chromosome deletion in a case of retinoblastoma. Ann Hum Genet 1963;27:171-

39 Wilson MG, Melnyk J, Towner JWJ. Retinoblastoma and deletion D(14) syndrome. F Med Genet 1969;6:322-7.

40 Taylor AI. Dq-, Dr and retinoblastoma. Humangenetik 1970;10:209-17.

41 Munier F, Pescia G, Jotterand-Bellomo M, et al. Constitutional karyotype in retinoblastoma. Case report and review of literature. Ophthalmic Paediatr Genet 1989;10:129-50.

42 Cowell JK, Hungerford J, Rutland P, Jay M. Genetic and cytogenetic analysis of patients showing reduced estercytogenetic analysis of patients showing reduced esterase-D levels and mental retardation fom a survey of 500 individuals with retin

43 Bunin GR, Emanuel BS, Meadows AT, et al. Frequency of $13 q$ abnormalities among 203 patients with retinoblastoma. f Natl Cancer Inst 1989;81:370-4.

44 Lemieux N, Richer CL. Chromosome evolution and highresolution analysis of leucocytes, bone marrow, and tumor cells of retinoblastoma patients. Am $\mathcal{F}$ Med Gene 1990;36:456-62.

45 Miller RW, Fraumeni JF Jr, Manning MD. Association of 
Wilms's tumor with aniridia, hemihypertrophy, and other congenital malformations. $N$ Engl $f$ Med 1964;270:922-7.

46 Pendergrass TW. Congenital anomalies in children with Wilms' tumor. A new survey. Cancer 1976;37:403-9.

47 Shannon RS, Mann JR, Harper E, et al. Wilms's tumour and aniridia: clinical and cytogenetic features. Arch Dis Child 1982;57:685-90.

48 Fraumeni JF Jr, Glass AG. Wilms's tumor and congenital aniridia. $\mathcal{F} A M A$ 1968;206:825-8.

49 Nakagome Y, Ise T, Sakurai $M$, et al. High-resolution studies in patients with aniridia-Wilms tumor association, Wilms tumor or related congenital abnormalities. Hum Genet 1984;67:245-8.

50 Hotta Y, Fujiki K, Ishida N, et al. High resolution Gbanding analysis in aniridia. Ophthalmic Paediatr Genet 1987;8:145-50.

51 Lyons LA, Martha A, Mintz-Hittner HA, et al. Resolution of the two loci for autosomal dominant aniridia, AN1 and AN2, to a single locus on chromosome $11 \mathrm{p} 13$. Genomics 1992;13:925-30.

52 Turleau C, de Grouchy J, Tournade MF, Gagnadoux MF, Junien C. Del $11 \mathrm{p}$ /aniridia complex: report of three patients and review of 37 observations from the literapatients and review of 37 observati

53 Turleau C, de Grouchy J, Nihoul-Fékété C, et al. Del11 13/nephroblastoma without aniridia. Hum Genet 1984;67:455-6.

54 Niikawa N, Fukushima Y, Taniguchi N, Iizuka S, Kajii T. Chromosome abnormalities involving $11 \mathrm{p} 13$ and low erythrocyte catalase activity. Hum Genet 1982;60:373-5.

55 Fantes JA, Bickmore WA, Fletcher JM, Ballesta F, Hanson $M$, van Heyningen $V$. Submicroscopic deletions at the WAGR locus, revealed by nonradioactive in situ hybridization. Am F Hum Genet 1992;51:1286-94.

56 Riccardi VM, Hittner HM, Strong LC, et al. Wilms tumor with aniridia/iris dysplasia and apparently normal chrowith aniridia/iris dysplasia and appar
mosomes. $\mathcal{F}$ Pediatr 1982;100:574-7.

57 Porteous DJ, Bickmore W, Christie S, et al. HRAS1selected chromosome transfer generates markers that selected chromosome transfer generates markers that colocalize aniridia- and genitourinary dysplasia-associ-
ated translocation breakpoints and the Wilms' tumor ated translocation breakpoints and the Wilms' tumor
gene within 11p13. Proc Natl Acad Sci USA gene within 11

58 Moore JW, Hyman S, Antonarakis SE, Mules EH, Thomas GH. Familial isolated aniridia associated with translocation involving chromosome 11 and 22 [t(11;22)(p13;q12.2)]. Hum Genet 1986;72:297-302.

59 Pettenati MJ, Weaver RG, Burton BK. Translocation $\mathrm{t}(5 ; 11)(\mathrm{q} 13.1 ; \mathrm{p} 13)$ associated with familial isolated aniridia. Am f Med Genet 1989;34:230-2.

60 Simola KOJ, Knuutila S, Kaitila I, Pirkola A, Pohja P. Familial aniridia and translocation $t(4 ; 11)(q 22 ; p 13)$ Familial aniridia and translocation t(4;1)(q22; 13
without Wilms' tumor. Hum Genet 1983;63:158-61.

61 Butler MG. Prader-Willi syndrome: current understanding of cause and diagnosis. Am 7 Med Genet 1990;35:31932 .

62 Robinson WP, Bottani A, Yagang X, et al. Molecular, cytogenetic, and clinical investigations of Prader-Will syndrome patients. Am f Hum Genet 1991;49:1219-34.

63 Hamabe J, Fukushima Y, Harada N, et al. Molecula study of the Prader-Willi syndrome: deletion, RFLP, and phenotype analyses in 50 patients. $\mathrm{Am} \mathcal{F}$ Med Genet 1991;41:54-63.

64 Winsor EJT, Welch JP. Prader-Willi syndrome associated with inversion

65 Fryns JP, Kleczkowska A, Decock P, Van den Berghe H. Angelman's syndrome and 15q11-13 deletions. $\mathcal{f}$ Med Genet 1989;26:538-40.

66 Hamabe J, Kuroki Y, Imaizumi K, et al. DNA deletion and its parental origin in Angelman syndrome patients. Am 7 Med Genet 1991;41:64-8.

67 Imaizumi K, Takada F, Kuroki Y, et al. Cytogenetic and molecular study of Angelman syndrome. Am $\mathfrak{f} \mathrm{Med}$ Genet 1990;35:314-18

68 Pembrey M, Fennell SJ, Van den Berghe J, et al. The association of Angelman's syndrome with deletion within 15q11-13. F Med Genet 1989;26:73-7.

69 Webb T, Clayton-Smith J, Cheng XJ, et al. Angelman syndrome with a chromosomal inversion 15 inv(p11q13) accompanied by a deletion in 15q11q13. F Med Genet 1992;29:921-4.

70 Ballabio A, Andria G. Deletions and translocations involving the distal short arm of the human $\mathrm{X}$ chromosome. Review and hypotheses. Hum Mol Genet 1992;1:221-7.

71 Matsumoto T, Kondoh, Yoshimoto M, et al. Complex glycerol kinase deficiency: molecular-genetic, cytogenetic, and clinical studies of five Japanese patients. $A m \mathcal{J}$ Med Genet 1988;31:603-16.

72 McCabe ERB, Towbin JA, van den Engh G, Trask BJ. $\mathrm{Xp} 21$ contiguous gene syndromes: deletion quantitation with bivariate flow karyotyping allows mapping of

patient breakpoints. Am f Hum Genet 1992;51:1277-85.
73 Wyandt HE, Grierson HL, Sanger WG, et al. Chromosome deletion of Xq25 in an individual with X-linked lymphoproliferative disease. $A m$ f Med Genet 1989;33:426-30.

74 Yang HM, Lund T, Niebuhr E, et al. Exclusion mapping of $12 \mathrm{X}$-linked disease loci and 10 DNA probes from the 104 .

75 Thomas NST, Ray PN, Worton RG, Harper PS. Molecular deletion analysis in Duchenne muscular dystrophy. $\mathcal{F}$ Med Genet 1986;23:509-15.
76 Therman E, Susman B. The similarity of phenotypic effects caused by $\mathrm{Xp}$ and $\mathrm{Xq}$ deletions in the human female: a hypothesis. Hum Genet 1990;85:175-83.

77 Schmidt M, Certoma A, Du Sart D, et al. Unusual X chromosome inactivation in a mentally retarded girl with an interstitial deletion Xq27: implications for the fragile $\mathrm{X}$ syndrome. Hum Genet 1990;84:347-52.

78 Schmidt $M$. Do sequences in Xq27.3 play a role in X inactivation? Am $\mathcal{F}$ Med Genet 1992;43:487-91.

79 Daniel A, Hook EB, Wulf G. Collaborative USA data on prenatal diagnosis for parental carriers of chromosome rearrangements: risks of unbalanced progeny. In: The cytogenetics of mammalian autosomal rearrangements. New York: Alan R Liss, 1988:73-162.

80 Mattei MG, Mattei JF, Ayme S, Giraud F. X-autosome translocation: cytogenetic characteristics and their consequences. Hum Genet 1982;61:295-309.

81 Schmidt M, Du Sart D. Functional disomies of the $\mathrm{X}$ chromosome influence the cell selection and hence the $\mathrm{X}$ inactivation pattern in females with balanced $\mathrm{X}$-autosome translocations: a review of 122 cases. Am $\mathcal{F}$ Med Some translocations: a

82 Korenberg JR, Rykowski MC. Human genome organization: Alu, Lines, and the molecular structure of metation: Alu, Lines, and the molecular structure of
phase chromosome bands. Cell 1988;53:391-400.

83 Holmquist GP. Chromosome bands, their chromatin flavors, and their functional features. Am $\mathcal{f}$ Hum Genet 1992;51:17-37.

84 Imaizumi K, Kuroki Y. Rubinstein-Taybi syndrome with de novo reciprocal translocation $\mathrm{t}(2 ; 16)(\mathrm{p} 13.3 ; \mathrm{p} 13.3)$ Am $\mathcal{F}$ Med Genet 1991;38:636-9.

85 Tommerup N, van der Hagen CB, Heiberg A. Tentative assignment of a locus for Rubinstein-Taybi syndrome to $16 \mathrm{p} 13.3$ by a de novo reciprocal translocation t(7;16)(q34; 13.3). Am f Med Genet 1992;44:237-41.

86 Lacombe D, Saura R, Taine L, Battin J. Confirmation of assignment of a locus for Rubinstein-Taybi syndrome to 16p13.3. Am ₹ Med Genet 1992;44:126-8.

87 Breuning MH, Dauwerse HG, Fugazza G, et al. Rubinstein-Taybi syndrome caused by submicroscopic deletions within 16p13.3. Am ₹ Hum Genet 1993;52:249-54

88 Wilkie AO, Buckle VJ, Harris PC, et al. Clinical features and molecular analysis of the alpha thalassemia/mental retardation syndromes. I. Cases due to deletions involving chromosome band 16p13.3. Am f Hum Genet 1990;46:1112-26.

89 Weinberg RA. Tumor suppressor genes. Science 1991;254:1138-46.

90 Kayes LM, Riccardi VM, Burke W, Bennett RL, Stephens $K$. Large de novo deletion in a patient with sporadic neurofibromatosis 1 , mental retardation, and dysmorphism. F Med Genet 1992;29:686-90.

91 Andersen LB, Tommerup N, Koch J. Formation of a mini-chromosome by excision of the proximal region of $17 \mathrm{q}$ in a patient with von Recklinghausen neurofibromatosis. Cytogenet Cell Genet 1990;53:206-10.

92 Schmidt MA, Michels VV, Deward W. Cases of neurofibromatosis with rearrangements of chromosome 17 involving band 17q11.2. Am F Med Genet 1987;28:771-7.

93 Ledbetter DH, Rich DC, O'Connell P, Leppert M, Carey JC. Precise localisation of NF1 to $17 \mathrm{q} 11.2$ by balanced translocation. Am f Hum Genet 1989;44:20-4.

94 Houston CS, Opitz JM, Spranger JW, et al. The campomelic syndrome: review, report of 17 cases, and followup on the currently 17-year-old boy first reported by Maroteaux et al in 1971. Am f Med Genet 1983;15:3-28.

95 Tommerup N, Schempp W, Meinecke P, et al. Assignment of an autosomal sex reversal locus (SRA1) and campomelic dysplasia (CMPD1) to $17 \mathrm{q} 24.3-\mathrm{q} 25.1$. Nature Genet 1993;4:170-4.

96 Maraia R, Saal HM, Wangsa D. A chromosome 17q de novo paracentric inversion in a patient with campomelic dysplasia; case report and etiologic hypothesis. Clin dysplasia; case report
Genet 1991;39:401-8.

97 Young ID, Zuccollo JM, Maltby EL, Broderick NJ. Campomelic dysplasia associated with a de novo 2q;17q

98 Bridge J, Sanger W, Mosher G, et al. Partial deletion of distal 17q. Am f Med Genet 1985;21:225-9.

99 Giannotti A, Alessandri A, Reale A, Digilio MC, Valoran MG. Partial deletion of the long arm of chromosome 17 Clinical case. Minerva Pediatr 1992;44:51-4.

100 Luke S, Bennett HS, Pitter JH, Verma RS. A new case of monosomy for 17q25-qter due to a maternal translocation $[\mathrm{t}(3 ; 17)(\mathrm{p} 12 ; \mathrm{q} 24)]$. Ann Genet (Paris) 1992;35:4850.

101 Ebensperger C, Jäger RJ, Lattermann U, et al. No evidence of mutations in four candidate genes for male sex determination/differentiation in sex-reversed XY females with campom

102 Henry I, Bonaïti-Pellié C, Junien C. Uniparental paternal disomy in a genetic cancer-predisposing syndrome Nature 1991;351:665-7.

103 Mannens M, Hoovers JMN, Redeker B, et al. Parenta imprinting of human chromosome region 11p15.3-pter involved in the Beckwith-Wiedemann syndrome and various human neoplasia. Eur $\mathcal{f}$ Hum Genet (submitted).

104 Nicholls RD, Knoll JHM, Butler MG, Karam S, Lalande $M$. Genetic imprinting suggested by maternal heterodisomy in non-deletion Prader-Willi syndrome. Nature 1989;342:281-5.

105 Verga V, Hall BK, Wang S, et al. Localization of the translocation breakpoint in a female with Menkes syn- 
drome to Xq13.2-q13.3 proximal to PGK-1. Am f Hum Genet 1991;48:1133-8.

106 Tümer Z, Tommerup N, Tønnesen T, et al. Mapping of the Menkes locus to Xq13.3 distal to the X-inactivation center by an intrachromosomal insertion of the segment Xq13.3-q21.2. Hum Genet 1992;88:668-72.

107 Tommerup N, Tümer Z, Tonnesen T, Horn N. A cytogenetic survey in Menkes disease. Implications for the genetic survey in Menkes disease. Implications for the detection of chromosomal rearrangements
disorders. $f$ Med Genet 1993;30:314-15.

108 Collins FA, Murphy DL, Reiss AL, et al. Clinical, biochemical, and neuropsychiatric evaluation of a patien with a contiguous gene syndrome due to a microdeletion Xp11.3 including the Norrie disease locus and monoamine oxidase (MAOA and MAOB) genes. $A m \mathcal{F} \mathrm{Med}$ Genet 1992;42:127-34.

109 Lupski JR, Wise CA, Kuwano A, et al. Gene dosage is a mechanism for Charcot-Marie-Tooth disease type $1 \mathrm{~A}$ Nature Genet 1992;1:29-33.

110 Chamberlin J, Magenis RE. Parental origin of de novo chromosome rearrangements. Hum Genet 1980;53:343-7.

111 Chandley AC. On the parental origin of de novo mutation in man. $\mathcal{F}$ Med Genet 1991;28:217-23.

112 Ejima Y, Sasaki MS, Kaneko A, Tanooka H. Types, rates, origin and expressivity of chromosome mutations involving $13 \mathrm{q} 14$ in retinoblastoma patients. Hum Genet 1988;79:118-23.

113 Kean VM, MacLeod HL, Thompson MW, et al. Paternal inheritance of translocation chromosomes in a $t(X ; 21)$ patient with $\mathrm{X}$ linked muscular dystrophy. $\mathcal{f}$ Med Genet 1986;23:491-3.

114 Bodrug SE, Roberson JR, Weiss L, et al. Prenatal identification of a girl with a $t(X ; 4)(p 21 ; q 35)$ translocation: molecular characterisation, paternal origin, and association with muscular dystrophy. $\mathscr{f}$ Med Genet 1990;27:426-32.

115 Robinson D, Boyd Y, Collinson M, Jacobs P. Determination of the parental origin of $\mathrm{X}$;autosome translocations by M27 $\beta$ methylation analysis. $\mathcal{J}$ Med Genet 1991;28:63-4.

116 Robinson DO, Boyd Y, Cockburn D, et al. The parental origin of de novo $\mathrm{X}$-autosome translocations in females with Duchenne muscular dystrophy revealed by M27 methylation analysis. Genet Res Camb 1990;56:135-40.

117 Kapur S, Higgins JV, Delp K, Rogers B. Menkes syndrome in a girl with $\mathrm{X}$-autosome translocation. $A m \mathcal{F}$ Med Genet 1987;26:503-10.

118 Bawle E, Tyrkus M, Lipman S, Bozimowski D. Aarskog syndrome: full male and female expression associated with an X-autosome translocation. $\mathrm{Am} \mathcal{F} \mathrm{Med}$ Genet 1984;17:595-602.

$119 \mathrm{Kaffe}$ S, Hsu LYF. Chromosome inversions in a series of 25.000 prenatal diagnoses: frequency and pregnancy outcome. Am ₹ Hum Genet 1990;47:A278(1097).

120 Groupe de Cytogeneticiens Français. Pericentric inversions in man. A French collaborative study. Ann Genet (Paris) 1986;29:129-68.

121 Groupe de Cytogeneticiens Français. Paracentric inversions in man. A French collaborative study. Ann Genet (Paris) 1986;29:169-76

122 Clayton-Smith J, Webb T, Pembrey ME, Nichols $M$ Malcolm S. Maternal origin of deletion 15q11-13 in $25 / 25$ cases of Angelman syndrome. Hum Gene 1992;88:376-8.

123 Petersen MB, Frantzen M, Antonarakis SE, et al. Comparative study of microsatellite and cytogenetic markers for detecting the origin of the nondisjoined chromosome 21 in Down syndrome. Am 7 Hum Genet 1992;51:516-25.

124 Purvis-Smith SG, Saville T, Manass S, et al. Uniparenta disomy 15 resulting from correction of an initial trisomy 15. Am ₹ Hum Genet 1992;50:348-50.

125 Cassidy SB, Lai LW, Erickson RP, et al. Trisomy 15 with loss of paternal 15 as a cause of Prader-Willi syndrome due to maternal disomy. Am f Hum Genet 1992;51:701-8.

126 Norman AM, Read AP, Clayton-Smith J, Andrews T, Donnai D. Recurrent Wiedemann-Beckwith syndrome with inversion of chromosome (11)(p11.2p15.5). Am J Med Genet 1992;42:638-41.

127 Lüdecke HJ, Johnson C, Wagner MJ, et al. Molecular definition of the shortest region of deletion overlap in the Langer-Giedion syndrome. Am 7 Hum Genet 1991;49:1197-206.

128 Davis LM, Stallard R, Thomas GH, et al. Two anonymous DNA segments distinguish the Wilms' tumor and aniridia locus. Science 1988;241:840-2.

129 Bodrug SE, Ray PN, Gonzalez IL, et al. Molecula analysis of a constitutional X-autosome translocation in female with muscular dystrophy. Science 1987;237:16204.

130 Bodrug SE, Burghes AH, Ray PN, Worton RG. Mapping of four translocation breakpoints within the Duchenn of four translocation breakpoints within the Duch

131 Meitinger T, Boyd Y, Anand R, Craig I. Mapping of Xp21 translocation breakpoints in and around the DMD gen by pulsed field gel electrophoresis. Genomics 1988;3:31522.

132 Giacalone JP, Francke U. Common sequence motifs at the rearrangement sites of a constitutional X/autosome translocation and associated deletion. Am f Hum Gene 1992;50:725-41.

133 Higgins MJ, Hansen MF, Cavenee WK, Lalande $M$. Molecular detection of chromosomal translocations that disrupts the putative retino

134 Mitchell CD, Cowell JK. Predisposition to retinoblastoma due to a translocation within the $4.7 \mathrm{R}$ locus. Oncogene $1989 ; 4: 253-7$

135 Viskochil D, Buchberg AM, Xu G, et al. Deletions and a translocation interrupt a cloned gene at the neurofibromatosis type 1 locus. Cell 1990;62:187-92.

136 Cremers FPM, van de pol DJR, van Kerkhoff LPM, Wieringa B, Ropers HH. Cloning of a gene that is rearranged in patients with choroideraemia. Nature rearranged in $1990 ; 347: 674-7$.

137 Tsukamoto $\mathrm{K}$, Tohma $\mathrm{T}$, Ohta $\mathrm{T}$, et al. Cloning and characterization of the inversion breakpoint at chromosome $2 \mathrm{q} 35$ in a patient with Waardenburg syndrome type I. Hum Mol Genet 1992;1:315-17.

138 Chelly J, Tümer Z, Tonnesen T, et al. Isolation of a candidate gene for Menkes disease that encodes for a potential heavy metal binding protein. Nature Genet 1993;3:14-19.

139 Stambolian D, Selleinger B, Derrington D, et al. Cytogenetic and molecular investigation of a balanced Xq13q Genet 1992;42:771-6.

140 Happle $R$. Tentative assignment of hypomelanosis of Ito to 9q33-qter. Hum Genet 1987;75:98-9.

141 de Grouchy J, Turleau C, Doussau de Bazignan M, Maroteaux P, Thibaud D. Incontinentia pigmenti (IP) and $r(X)$. Tentative mapping of the IP locus to the $X$ juxtacentromeric region. Ann Genet (Paris) 1985;28:86-9.

142 Bernstein R, Dawson B, Kohl R, Jenkins T. X;15 translocation in a retarded girl: $X$ inactivation pattern and attempt to localise the hexosaminidase $\mathrm{A}$ and other loci. $\mathcal{F}$ Med Genet 1979;16:254-62.

143 Gilgenkrantz S, Tridon P, Pinel-Briquel N, Beurey J, Weber $M$. Translocation $(X ; 9)(p 11 ; q 34)$ in a girl with incontinentia pigmenti (IP): implications for the regional ssignment of the IP locus to Xp11? Ann Genet (Paris) 1985;28:90-2.

144 Kajii T, Tsukahara M, Fukushima Y, et al. Translocation (X;13)(p11.21;q12.3) in a girl with incontinentia pig1985;28:219-23.

145 Hodgson SV, Neville B, Jones RWA, Fear C, Bobrow M Two cases of $\mathrm{X} /$ autosome translocation in females with incontinentia pigmenti. Hum Genet 1985;71:231-4.

146 Cannizzaro LA, Hecht F. The gene for incontinentia pigmenti maps to band Xp11 with an $(\mathrm{X} ; 10)(\mathrm{p} 11 ; \mathrm{q} 22)$ ranslocation. Clin Genet 1987:32:66-9.

147 Bitoun P, Philippe C, Cherif M, Mulcahy MT, Gilgenkrantz $S$. Incontinentia pigmenti (type 1 ) and $X ; 5$-translocation. Ann Genet (Paris) 1992;35:51-4.

148 Sefiani A, Abel L, Heuertz S, et al. The gene for incontinentia pigmenti is assigned to Xq28. Genomics 1989;4:427-9.

149 Harris A, Lankester S, Haan E, et al. The gene for incontinentia pigmenti: failure of linkage studies using DNA probes to confirm cytogenetic localization. Clin Genet 1988;34:1-6.

150 Moss C, Burn J. Genetic counselling in hypomelanosis of Ito: case report and review. Clin Genet 1988;34:109-15.

151 Flannery DB. Pigmentary dysplasias, hypomelanosis of Ito, and genetic mosaicism. Am ₹ Med Genet 1990;35:1821.

152 Sefiani A, Heuertz S, Turleau C, et al. Incontinentia pigmenti: $\mathrm{Xp}$ breakpoint is not the same in a case of $r(X)$ and in $\mathrm{X}$ /autosome translocations. Ann Genet (Paris) 1989;32:149-51.

153 Crolla JA, Gilgenkranz S, de Grouchy J, Kajii T, Bobrow $M$. Incontinentia pigmenti and $\mathrm{X}$-autosome translocations. Non-isotopic in situ hybridization with an $\mathrm{X}$ centromere specific probe $(\mathrm{pSV} 2 \mathrm{X} 5)$ reveals a possible $\mathrm{X}$-centromeric breakpoint in one of five published cases. Hum Genet 1989;81:269-72.

154 Gorski JL, Burright EN, Reyner EL, et al. Isolation of DNA markers from a region between incontinentia pigDNA markers from a region between incontinentia pigmenti 1 (IP1) X-chromosomal translocation breakpoints by a comparative PCR analysis of a radiation hybric
subclone mapping panel. Genomics 1992;14:649-56.

155 Tommerup N, Lothe RA. Constitutional ring chromosomes and tumour suppressor genes. $f$ Med Genet 1992;29:879-82.

156 Nisen P, Stamberg J, Ehrenpreis R, et al. The molecular basis of severe hemophilia B in a girl. $N$ Engl f Med 1986;315:1139-42.

157 Journel H, Melki J, Turleau C, Munnich A, de Grouchy J. Rett phenotype with X/autosome translocation: possible mapping to the short

158 Zoghbi HY, Ledbetter DH, Schultz R, Percy AK, Glaze DG. A de novo $\mathrm{X} ; 3$ translocation in Rett syndrome. $A m \mathcal{F}$ Med Genet 1990;35:148-51.

159 Ellison KA, Fill CP, Terwilliger J, et al Examination of $\mathrm{X}$ chromosome markers in Rett syndrome: exclusion mapping with a novel variation on multilocus linkage analyping with a novel variation on multilocus
sis. Am $\mathcal{f}$ Hum Genet 1992;50:278-87.

160 Tommerup N Nielsen F A familial reciprocal translocation $t(3 ; 7)(p 21.1 ; p 13)$ associated with the Greig polysyndactyly-craniofacial dysmorphism syndrome. $A m \mathcal{F} \mathrm{Med}$ Genet 1983;16:313-21.

161 Krüger G, Götz J, Kvist U, et al. Greig syndrome in a large kindred due to reciprocal chromosome translocation $\mathrm{t}(6 ; 7)(\mathrm{q} 27 ; \mathrm{p} 13)$. Am $\mathcal{f}$ Med Genet 1989;32:411-16.

162 Vortkamp A, Thias U, Gessler M, et al. A somatic cell hybrid panel and DNA probes for physical mapping of human chromosome 7p. Genomics 1991;11:737-43.

163 Wagner K, Kroisel PM, Rosenkranz W. Molecular and cytogenetic analysis in two patients with microdeletions 
of $7 p$ and Greig syndrome: hemizygosity for PGAM-2 and TCRG genes. Genomics 1990;8:487-91.

164 Pettigrew AL, Greenberg F, Caskey CT, Ledbetter DH. Greig syndrome associated with an interstitial deletion of 7p: confirmation of the localization of Greig syndrome to 7p: confirmation of the localization

165 Brueton L, Huson SM, Winter RM, et al. Chromosomal localization of a developmental gene in man: direct DNA analysis demonstrates that Greig cephalopolysyndactyly maps to 7p13. Am f Med Genet 1988;31:799-804.

166 Vortkamp A, Gessler M, Grzeschik KH. GLI3 zinc-finger gene interrupted by translocations in Greig syndrome families. Nature 1991;352:539-40.

167 Wilson GN, Sauder SE, Bush M, Beitins IZ. Phenotypic delineation of ring chromosome 15 and Russell-Silver syndromes. F Med Genet 1985;22:237-40.

168 Yunis JJ, Ramsay NKC. Familial occurrence of the aniridia-Wilms' tumor syndrome with deletion $11 \mathrm{p} 13-14.1$. $\mathrm{F}$ Pediatr 1980;96:1027-30.

169 Kousseff BG, Agatucci A. Aniridia-Wilms tumor association. $\mathcal{f}$ Pediatr 1981;98:676-7.

170 Nakagome $Y$, Nagahara $N$. High-resolution studies in patients with aniridia-Wilms tumor association. Hum patients with aniridi

171 Cross I, Delhanty J, Chapman P, et al. An intrachromosomal insertion causing $5 \mathrm{q} 22$ deletion and familial adenomatous polyposis coli in two generations. $\mathcal{F}$ Med Genet 1992;29:175-9.

172 Williamson RA, Donlan MA, Dolan CR, et al. Familial insertional translocation of a portion of $3 \mathrm{q}$ into $11 \mathrm{q}$ resulting in duplication and deletion of region $3 \mathrm{q} 22.1-\mathrm{q} 24$ in different offspring. $A m \mathcal{F}$ Med Genet 1981;9:105-11.

173 Weissenbach J, Gyapay G, Dib C, et al. A second generation linkage map of the human genome. Nature 1992;359:794-801.

174 Schwartz M, Rosenberg T, Niebuhr E, et al. Choroideremia: further evidence for assignment of the locus to mia: further evidence for assignment of

175 Tabor A, Andersen O, Lundsteen C, Niebuhr E, Sardemann $H$. Interstitial deletion in the 'critical region' of the
long arm of the $X$ chromosome in a mentally retarded long arm of the $X$ chromosome in a mentally retarded
boy and his normal mother. Hum Genet 1983;64:196-9.

176 Chumakov I, Rigault P, Guillou S, et al. Continuum of overlapping clones spanning the entire human chromosome 21q. Nature 1992;359:380-7.

177 Foote S, Vollrath D, Hilton A, Page DC. The human Y chromosome: overlapping DNA clones spanning the euchromatic region. Science 1992;258:60-6.

Appendix This appendix contains references not mentioned in the text, listed alphabetically according to locus, including references to rearrangements included in tables 1 and 2, and some selected key references. Locus specific cross references to the text are included.

AGS Alagille syndrome

Anad F, Burn J, Matthews D, et al. Alagille syndrome and deletion of 20p. $\mathcal{F}$ Med Genet 1990;27:729-37.

179 Teebi AS, Krishna Murthy DS, Ismail EAR, Redha AA. Alagille syndrome with de novo $\operatorname{del}(20)(\mathrm{p} 11.2) . \mathrm{Am} \mathfrak{f}$ Med Genet 1992;42:35-8.

AHC Adrenal hypoplasia, congenital ${ }^{72}$

illers DAM, Weleber RG, Powell BR, et al. Åland Island eye disease (Forsius-Eriksson ocular albinism) and an Xp21 deletion in a patient with Duchenne muscular dystrophy, glycerol kinase deficiency, and congenital adrenal hypoplasia. Am $\mathcal{F}$ Med Genet 1990;36:23-8.

AIC Aicardi syndrome

Naritomi K, Izumikawa Y, Nagataki S, et al. Combined Goltz and Aicardi syndromes in a terminal Xp deletion: are they a contiguous gene syndrome? $A m f \mathrm{Med}$ Genet 1992;43:839-43.

${ }^{182}$ Ropers HH, Zuffardi O, Bianchi E, Tiepolo L. Agenesis of corpus callosum, ocular, and skeletal anomalies (Xlinked dominant Aicardi's syndrome) in a girl with balanced X/3 translocation. Hum Genet 1982;61:364-8.

AIED Åland island eye disease ${ }^{180}$

ANCR Angelman syndrome (happy puppet) ${ }^{65-69122}$

Williams CA, Zori RT, Stone JW, et al. Maternal origin of 15q11-13 deletions in Angelman syndrome suggests a role for genomic imprinting. Am $\mathcal{f}$ Med Genet 1990;35:350-3

AN2 Aniridia 215 18 24 45-60 128 168-170

ANK1 Spherocytosis type II (ankyrin defect) imberling WJ, Fulbeck T, Dixon L, Lubs HA. Localization of spherocytosis to chromosome 8 or 12 and report of a family with spherocytosis and a reciprocal translocation. Am ₹ Hum Genet 1975;27:586-94.

185 Bass EB, Smith SW Jr, Stevenson RE, Rosse WF. Further evidence for location of the spherocytosis gene on chromosome 8. Ann Intern Med 1983;99:192-3.

186 Chilcote RR, le Beau MM, Dampier C, et al. Association of red cell spherocytosis with deletion of the short arm of chromosome 8. Blood 1987;69:156-9.

187 Kitatani M, Chiyo M, Oxaki M, Shike S, Miwa S. Localization of the spherocytosis gene to chromosome segment tion of the spherocytosis gene to chrom

188 8p11.22-8p21. Hum Genet 1988,78:94-5. cyes ankyrin gene on chromosome 8. Nature 1990;345:736-9. APC Adenomatous polyposis coli, incl Gardner syn-
drome ${ }^{171}$
189 Herrera L, Kakati S, Gibas L, Pietrzak E, Sandberg AA. Gardner syndrome in a man with an interstitial deletion of 5q. Am 7 Med Genet 1986;25:473-6.

190 Hockey KA, Mulcahy MT, Montgomery P, Levitt S. Deletion of chromosome $5 \mathrm{q}$ and familial adenomatous polyposis. I Med Genet 1989;26:61-2

${ }^{191}$ Kobayashi T, Narahara K, Yokoyama Y, et al. Gardner syndrome in a boy with interstitial deletion of the long arm of chromosome 5. Am F Med Genet 1991;41:460-3.

2 Lindgren V, Bryke CR, Ozcelik T, Yang-Feng TL Francke U. Phenotypic, cytogenetic, and molecular studies of three patients with constitutional deletions of chromosome 5 in the region of the gene for familial adenomatous polyposis. Am f Hum Genet 1992;50:98897.

\section{AZF Azoospermia}

Anderson M, Page DC, Pettay D, et al. Y;autosome translocations and mosaicism in the aetiology of $45, \mathrm{X}$ maleness: assignment of fertility factor to distal Yq11. Hum Genet assignment

194 Bardoni B, Zuffardi O, Guioli S, et al. A deletion map of the human Yq11 region: implications for the evolution of the $Y$ chromosome and tentative mapping of a locus involved in spermatogenesis. Genomics 1991;11:443-51.

195 Ma K, Sharkey A, Kirsch S, et al. Towards the molecular localisation of the AZF locus: mapping of microdeletions in azoospermic men within 14 subintervals of interval 6 of the human Y chromosome. Hum Mol Genet 1992;1:2933.

96 Diaz-Castanos LR, Rivera H, Gonzales-Montes RM, Diaz M. Translocation $(\mathrm{Y} ; 19)(\mathrm{q} 12 ; \mathrm{q} 13)$ and azoospermia. Ann Genet (Paris) 1991;34:27-9.

BPES Blepharophimosis, ptosis, epicanthus inversus

97 De Almeida JCC, Llerena JC Jr, Neto JBG. Another example favouring the location of BPES at 3q2. $f$ Med Genet 1993;30:86.

198 De Die-Smulders CEM, Engelen JJM, Donk JM, Fryns JP. Further evidence for the location of the BPES gene at 3q2. F Med Genet 1991;28:725.

199 Fujita H, Meng J, Kawamura M, et al. Boy with a chromosome $\operatorname{del}(3)(\mathrm{q} 12 \mathrm{q} 23)$ and blepharophimosis syndrome. Am ₹ Med Genet 1992;44:434-6.

200 Fukushima Y, Wakui K, Nishida T, Ueoka Y. Blepharophimosis syndrome and a de novo balanced autosomal translocation $[46, \mathrm{XY}, \mathrm{t}(3 ; 4)(\mathrm{q} 23 ; \mathrm{p} 15.2)]$. Possible location of blepharophimosis syndrome to 3q23. Am $\mathcal{F}$ Hum Genet 1990;47:A29.

201 Jewett T, Rao PN, Weaver RG, et al. Blepharophimosis syndrome (BPES) associated with del 3q22: gene assignment to the interphase of band 3q22-q23. Am $\mathcal{F ~ H u m ~}$ ment to the interphase of
Genet 1992;51(suppl):A81.

BWS Beckwith-Wiedemann syndrome ${ }^{102} 103126$
Brown KW, Gardner A, Williams JC, et al. Paternal origin of $11 \mathrm{p} 15$ duplications in the Beckwith-Wiedemann syndrome. Cancer Genet Cytogenet 1992;58:55-70.

${ }^{203}$ Haas OA, Zoubek A, Grumayer ER, Gadner H. Constitutional interstitial deletion of $11 \mathrm{p} 11$ and pericentric inversion of chromosome 9 in a patient with Wiedemann-Beckwith syndrome and hepatoblastoma. Cancer Genet Cytogenet 1986;23:95-104.

204 Pueschel SM, Padre-Mendoza T. Chromosome 11 and Beckwith-Wiedemann syndrome. $\mathcal{F}$ Pediatr $1984 ; 104$ : 484-5.

${ }^{205}$ Schmutz SM. Deletion of chromosome 11(p11p13) in a patient with Beckwith-Wiedemann syndrome. Clin Genet 1986;30:154-6.

Co6 Ballabio Androdysplasia punctata $1^{70}$ zation of human $\mathrm{X} / \mathrm{Y}$ translocations suggests their aetiology through aberrant exchange between homologous logy through aberrant exchange between homologous

sequences on Xq and Yq. Ann Hum Genet 1989;53:9-14.
CMPD1/SRA1 Campomelic dysplasia/sex reversal, autosomal $1^{94-97101}$

CMT1A Charcot-Marie-Tooth neuropathy $1^{109}$

CRS1 Craniosynostosis, syndromic 1

Motegi T, Ohuchi M, Ohtaki C, et al. A craniosynostosis in a boy with a del(7) (p15.3p21.3): assignment by deletion mapping of the critical segment for craniosynostosis to the mid-portion of $7 \mathrm{p} 21$. Hum Genet 1985;71:160-2.

208 Speleman F, Craen M, Leroy J. De novo terminal deletion 7 p22.1 $\rightarrow$ pter in a child without craniosynostosis. $\mathcal{f} \mathrm{Med}$ Genet 1989;26:528-32.

\section{CYBB Chronic granulomatous disease}

yer-Pokora B, Kunkel LM, Monaco AP, et al. Cloning of the gene for an inherited human disorder-chronic granulomatous disease-on the basis of its chromosomal location. Nature 1986;322:32-8.

MC, Fischer A, et al. Xp21 DNA microdeletion in a patient with chronic granulomatous disease, retinitis pigmentosa, and McLeod phenotype. Hum Genet 1988;80:85-9.

DFN3 Deafness, conductive, with fixed stapes ${ }^{271}$

Reardon W, Roberts S, Phelps PD, et al. Phenotypic evidence for a common pathogenesis in X-linked deafness pedigrees and in $\mathrm{Xq} 13-\mathrm{q} 21$ deletion related deafness. Am $\Im$ Med Genet 1992;44:513-17.

DGCR1 DiGeorge syndrome 1

Augusseau S, Jouk S, Jalbert P, Prieur M. DiGeorge syndrome and 22q11 rearrangements. Hum Genet

1986;74:206.
213 Carey AH, Roach S, Williamson R, et al. Localization of 27 DNA markers to the region of human chromosome 22q11-pter deleted in patients with the DiGeorge syndrome and duplicated in the der22 syndrome. Genomics
$1990 ; 7: 299-306$. 
${ }^{214}$ Greenberg F, Elder FFB, Haffner P, Northrup H, Ledbetter DH. Cytogenetic findings in a prospective series of patients with DiGeorge anomaly. Am f Hum Genet 1988;43:605-11.

215 Driscoll DA, Budarf ML, Emanuel BS. A genetic etiology for DiGeorge syndrome: consistent deletions and microfor DiGeorge syndrome: consistent deletions and micro-

216 Scambler PJ, Carey AH, Wyse RKH, et al. Microdeletions within 22q11 associated with sporadic and familial DiGeorge syndrome. Genomics 1991;10:201-6.

${ }^{217}$ Wilson DI, Cross IE, Goodship JA, et al. A prospective cytogenetic study of 36 cases of DiGeorge syndrome. $A m$ f Hum Genet 1992;51:957-63.

DGCR2 DiGeorge syndrome $2^{214}$, Garofalo S. T cell mmunodeficiency in a patient with $10 \mathrm{p}$ deletion syndrome. F Pediatr 1989;115:330.

DMD/BMD Duchenne and Becker muscular dys-

219 Boyd Y, Buckle V, Holt S, et al. Muscular dystrophy in girls with X;autosome translocations. F Med Genet 1986;23: 484-90.

${ }^{220}$ Boyd Y, Buckle VJ. Cytogenetic heterogeneity of translocations associated with Duchenne muscular dystrophy. Clin Genet 1986;29:108-15.

221 Boyd Y, Cockburn D, Holt S, et al. Mapping of 12 translocation breakpoints in the Xp21 region with respect to the locus for Duchenne muscular dystrophy. Cytogenet Cell Genet 1988;48:28-34.

${ }^{222}$ Monaco AP, Neve RL, Coletti-Feener C, et al. Isolation of candidate CDNA for portions of the Duchenne muscular dystrophy gene. Nature 1986:323:646-50.

${ }^{223}$ Ray PN, Belfall B, Duff C, et al. Cloning of the breakpoint of an $\mathrm{X} ; 21$ translocation associated with Duchenne musof an X;21 translocation associated with Duc

EDA Ectodermal dysplasia, anhidrotic (hypohidrotic)

Limon J, Filipiuk J, Nedoszytko B, et al. X-linked anhidrotic ectodermal dysplasia and de novo $\mathrm{t}(\mathrm{X} ; 1)$ in a female. tic ectodermal dysplasia and

${ }^{225}$ MacDermot KD, Hultén $M$. Female with hypohidrotic ectodermal dysplasia and de novo $(\mathrm{X} ; 9)$ translocation Clinical documentation of the AnLy cell line case. Hum Genet 1990;84:577-9.

226 Plougastel B, Couillin P, Blanquet V, et al. Mapping around the Xq13.1 breakpoints of two X/A translocations in hypohidrotic ectodermal dysplasia (EDA) female patients. Genomics 1992;14:523-5.

227 Turleau C, Niaudet P, Cabanis MO, et al. X-linked hypohidrotic ectodermal dysplasia and $t(X ; 12)$ in a female. Clin Genet 1989;35:462-6.

228 Zonana J, Roberts SH, Thomas NS, Harper PS. Recognition and reanalysis of a cell line from a manifesting female with $\mathrm{X}$ linked hypohidrotic ectodermal dysplasia and an $\mathrm{X}$;autosome balanced translocation. $\mathcal{f}$ Med Gene 1988;25:383-6

F9 Haemophilia $B$ (coagulation factor IX deficiency) Vianna-Morgante AM, Batista DAS, Levisky RB, Zatz M $\mathrm{X}$;autosomal translocations in females with $\mathrm{X}$-linked recessive diseases. 7th Int Congr Hum Genet (Berlin) 1987;I:97.

FGDY Aarskog syndrome ${ }^{118}$

GCPS Greig cephalopolysyndactyly ${ }^{160-166}$

GFDH Goltz focal dermal hypoplasia ${ }^{70}$

GK Glycerol kinase deficiency ${ }^{71}$

230 Walker AP, Muscatelli F, Monaco AP. Isolation of the human glycerol kinase gene by positional cloning. Hum Mol Genet 1993;2:107-14.

HLD Huntington-like disease
${ }_{231}$ Froster-Iskenius UG, Hayden MR, Wang HS, et al. A family with Huntington disease and reciprocal translocation 4;5. Am ₹ Hum Genet 1986;38:759-67.

${ }^{232}$ Steele MW, Wenger SL, Chorazy A, et al. Chromosome site 4q21 and Huntington like disease (HLD). Am $\mathcal{~ H u m}$ Genet 1987;41:A85.

HMRD Haemoglobin $H$ disease/mental retardation (deletion type)

HPE2 Holoprosencephaly 2
${ }_{233}$ Hecht BKM, Hecht F, Münke M. Forebrain cleavage gene causing holoprosencephaly: deletion mapping to chromosome band 2p21. Am $\mathcal{J}$ Med Genet 1991;40:130.

HPE3 Holoprosencephaly 3

Münke M. Clinical, cytogenetic, and molecular approaches to the genetic heterogeneity of holoprosencephaly. $A m \mathcal{F}$ Med Genet 1989;34:237-45.

235 Hatziioannou A, Krauss CM, Lewis MB, Halazonetis TD Familial holoprosencephaly associated with a translocation breakpoint at chromosomal position $7 \mathrm{q} 36 . \mathrm{Am} f$ Med Genet 1991;40:201-5.

${ }^{236}$ Lurie IW, Ilyina HG, Podleschuk LV, Gorelik LB, Zaletajev DV. Chromosome 7 abnormalities in parents of children with holoprosencephaly and hydronephrosis Am $\mathcal{F}$ Med Genet 1990;35:286-8.

${ }^{237}$ Gurrieri F, Trask BJ, van den Engh G, et al. Physical mapping of the holoprosencephaly critical region in 7q36. Nature Genet 1993;3:247-51.

HPE4 Holoprosencephaly 4

38 Cohen MM. Perspectives on holoprosencephaly. Part III Spectra, continuities, and discontinuities. $\mathrm{Am} \mathcal{f} \mathrm{Med}$ Genet 1989;35:271-88

HSCR Hirschsprung disease
Bottani A, Xie Y, Binkert F, Schinzel A. A case of Hirschsprung disease with a chromosome 13 microdeletion, del(13)(q32.3q33.2): potential mapping of one distion, del(13)(q32.3q33.2): potential mapp

240 Lamont MA, Fitchett M, Dennis NR. Interstitial deletion of distal 13q associated with Hirschsprung's disease. $f$ Med Genet 1989;26:100-4.

${ }^{241}$ Kiss $P$, Osztovics $M$. Association of $13 q$ deletion and Hirschsprung's disease. $\mathcal{F}$ Med Genet 1989;26:793-6.

IDS Hunter disease (iduronate-2-sulphatase deficiency)

${ }^{242}$ le Guern E, Couillin P, Oberlé I, Ravise N, Boue J. More precise localization of the gene for Hunter syndrome. Genomics 1990;7:358-62.

243 Mossman J, Blunt S, Stephen R, Jones EE, Pembrey M. Hunter's disease in a girl: association with $\mathrm{X} ; 5$ chromosomal translocation disrupting the Hunter gene. Arch Dis Child 1986;58:911-15.

IP1 Incontinentia pigmenti $1^{140-154}$

KAL1 Kallmann syndrome $1^{70}$

LGCR Langer-Giedion syndrome ${ }^{127}$

44 Bühler EM, Bühler UK, Beutler C, Fessler R. A final word on the tricho-rhino-phalangeal syndromes. Clin Genet 1987;31:273-5.

245 Gorlin RJ, Cervenka J, Bloom BA, Langer LO Jr. No chromosome deletion found on prometaphase banding in two cases of Langer-Giedion syndrome. Am $\mathcal{F}$ Med Genet 982;13:345-7.

${ }^{246}$ Ogle RF, Dalzell P, Turner G, Wass D, Yip MY. Multiple exostoses in a patient with $\mathrm{t}(8 ; 11)(\mathrm{q} 24.11 ; \mathrm{p} 15.5)$. $\mathcal{F}$ Med Genet 1991;28:881-3.

${ }^{247}$ Shabtai F, Sandowski U, Nissimow R, Klar D, Halbrecht I. Familial syndrome with some features of the LangerGiedion syndrome, and paracentric inversion of chromosome 8 , inv 8 (q11.23-q21.1). Clin Genet 1985;27:600-5.

248 Turleau C, Chavin-Colin F, de Grouchy J, et al. LangerGiedion syndrome with and without del $8 \mathrm{q}$ : assignment of critical segment to 8q23. Hum Genet 1982;62:183-7.

LYP Lymphoproliferative syndrome, $X$ linked $^{73}$

MBS Moebius syndrome

Slee JJ, Smart RD, Viljoen DL. Deletion of chromosome 13 in Moebius syndrome. $\mathcal{F}$ Med Genet 1991;28:413-14.

${ }^{250}$ Ziter FA, Wiser WC, Robinson A. Three generation pedigree of a Moebius syndrome variant with chromosome translocation. Arch Neurol 1977;34:437-42.

MDCR Miller-Dieker synd

${ }_{251}$ Mercer JFB, Livingstone J, Hall B, et al. Isolation of a partial candidate gene for Menkes disease by positional partial candidate gene for Menkes

252 Vulpe C. Levinson B, Whitney S, Packman S, Gitschier J. Isolation of a candidate gene for Menkes disease and evidence that it encodes a copper-transporting ATPase. Nature Genet 1993;3:7-13.

MRX2 Mental retardation, $X$ linked ${ }^{70}$

NDP Norrie disease $e^{108}$

53 Ohba N, Yamashita T. Primary vitreoretinal dysplasia resembling Norrie's disease in a female: association with $\mathrm{X}$ autosome chromosomal translocation. Br $\mathcal{F}$ Ophthalmol 1986;70:64-71.

${ }^{254}$ Pettenati MJ, Rao PN, Weaver RG Jr, Thomas IT, McMahan MR. Inversion $(\mathrm{X})(\mathrm{p} 11.4 \mathrm{q} 22)$ associated with Norrie disease in a four generation family. Am 7 Med Genet 1993;45:577-80.

NF1 Neurofibromatosis 1 (von Recklinghausen) (vo-93135 $^{90}$

NF2 Neurofibromatosis 2 (central, bilateral acoustic neurinoma)

${ }^{255}$ Arai E, Ikeuchi T, Karasawa S, et al. Constitutional translocation $\mathrm{t}(4 ; 22)$ (q12;q12.2) associated with neurofibromatosis type 2. Am f Med Genet 1992;44:163-7.

OA1 Ocular albinism 1 (Nettleship-Falls type) ${ }^{70}$

OCRL Oculocerebrorenal syndrome of Lowe

${ }^{256}$ Hodgson SV, Heckmatt JZ, Hughes E, Crolla JA, Dubowitz V, Bobrow $M$. A balanced de novo X/autosome translocation in a girl with manifestations of Lowe syndrome. Am f Med Genet 1986;23:837-47.

257 Mueller OT, Hartsfield JK Jr, Gallardo LA, et al. Lowe oculocerebrorenal syndrome in a female with a balanced $\mathrm{X} \cdot 20$ translocation: mapping of the $\mathrm{X}$ chromosome $\mathrm{X} ; 20$ translocation: mapping of the $\mathrm{X}$ chron
breakpoint. Am $\mathcal{F}$ Hum Genet 1991;49:804-10.

PAX6 Paired box gene 6 associated with aniridia ${ }^{19} 24$

PBT Piebald trait

258 Yamamoto Y, Nishimoto H, Ikemoto S. Interstitial deletion of the proximal long arm of chromosome 4 associated with father-child incompatibility within the Gc-system. Probable reduced gene dosage effect and partial piebald trait. Am f Med Genet 1989;32:520-3.

259 Funderburk SJ, Crandall BF. Dominant piebald trait in a retarded child with a reciprocal translocation and small intercalary deletion. Am f Hum Genet 1974;26:715-22.

260 Hoo JJ, Haslam RHA, van Orman C. Tentative assignment of piebald trait gene to chromosome band $4 \mathrm{q} 12$. Hum of piebald trait gene

261 Lacassie Y, Thurmon TF, Tracy MC, Pelias MZ. Piebald trait in a retarded child with interstitial deletion of chromosome 4. Am f Hum Genet 1977;29:641-2.

PWCR Prader-Willi syndrome RBility $^{62-44112133134139}$

RP3 Retinitis pigmentosa 3

McDowell C, Burghes AH, Anson-Cartwright S, et al. Xlinked retinitis pigmentosa (XLRP): mapping of the gene to Xp21, pulsed field gel electrophoresis (PFGE) of the region and cloning strategies. Am $\mathcal{F}$ Hum Gene 1990;47:A256(1009)

RSTS Rubinstein-Taybi syndrome $e^{84-87}$

SHFD1 Split hand and foot deformity 1

${ }^{263}$ Hasegawa T, Hasegawa Y, Assamura S, et al. EEC syndrome (ectrodactyly, ectodermal dysplasia and cleft lip palate) with a balanced reciprocal translocation between 
$7 \mathrm{q} 11.21$ and $9 \mathrm{p} 12$ (or $7 \mathrm{p} 11.2$ and 9q12). Clin Genet 1991;40:202-6.

264 Qumsiyeh MB. EEC syndrome (ectrodactyly, ectodermal dysplasia and cleft lip/palate) is on 7p11.2-q21.3. Clin Genet 1992;42:101.

${ }^{265}$ Rivera H, Sanchez-Corona J, Burgos-Fuentes VR, Melendez-Ruiz MJ. Deletion of $7 \mathrm{q} 22$ and ectrodactyly. Genet dez-Ruiz MJ. Deletion

266 Sharland M, Patton MA, Hill L. Ectrodactyly of hands and feet in a child with a complex translocation including 7q21.2. Am f Med Genet 1991;39:413-14.

SRY Testis-determining factor

Disteche CM, Casanova M, Saal H, et al. Small deletions of the short arm of the $\mathrm{Y}$ chromosome in 46,XY females. Proc Natl Acad Sci USA 1986;83:7841-4.

${ }^{268}$ Ferguson-Smith MA, Cooke A, Affara NA, Boyd E, Tolmie JL. Genotype-phenotype correlations in XX males and their bearing on current theories of sex determination. Hum Genet 1990;84:198-202.

269 Sinclair AH, Berta P, Palmer MS, et al. A gene from the human sex-determining region encodes a protein with homology to a conserved DNA-binding motif. Nature homology to a
1990;346:240-4.

SS Short stature, $X$ linked ${ }^{70}$

270 Ogata T, Matsuo N, Shimuzu N. A ring $X$ chromosome, $46, \mathrm{Y}, \mathrm{r}(\mathrm{X})(\mathrm{p} 22.33 \mathrm{q} 28)$, as a cause of extreme short stature $46, Y, r(X)(p 22.33 q 28)$, as a cause of extreme
in a male. Am 7 Med Genet $1990 ; 35: 241-4$.

STS $\mathrm{X}$ linked ichthyosis

TCD Choroideraemia ${ }^{37} 136174175$

${ }_{271}$ Cremers FP, Van den Pol DJR, Diergaarde PJ, et al. Physical fine mapping of the choroideremia locus using $\mathrm{Xq} 21$ deletions associated with complex syndromes. Genomics 1989;4:41-6.

${ }^{272}$ Kaplan J, Gilgenkrantz S, Dufier JL, Frézal J. Choroideremia and ovarian dysgenesis associated with an $\mathrm{X} ; 7$ de novo balanced translocation (HGM10). Cytogenet Cell Genet 1989;51:1022.

${ }^{273}$ Merry DE, Jänne PA, Landers JE, Lewis RA, Nussbaum $\mathrm{RL}$. Isolation of a candidate gene for choroideraemia. RL. Isolation of a candidate gene for ch
Proc Natl Acad Sci USA 1992;89:2135-9.

274 Siu VM, Gonder JR, Jung JH, Sergovich FR, Flintoff WF Choroideremia associated with an X-autosomal transloChoroideremia associated with an X-

TKC Torticollis, keloids, cryptorchidism, and renal dysplasia

${ }^{275}$ Zuffardi O, Fraccaro M. Gene mapping and serendipity. The locus for torticollis, keloids, cryptorchidism and renal dysplasia (31430, McKusick) is at Xq28, distal to the G6PD locus. Hum Genet 1982;62:280-1

TRP1 Trichorhinophalangeal syndrome 1

Fryns JP, Van den Berghe H. 8q24.12 interstitial deletion in trichorhinophalangeal syndrome type I. Hum Genet 1986;74:188-9.
277 Goldblatt J, Smart RD. Tricho-rhino-phalangeal syndrome without exostoses, with an interstitial deletion of $8 \mathrm{q} 23$. Clin Genet 1986;29:434-8.

${ }^{278}$ Hamers A, Jongbloet P, Peeters G, Fryns JP, Geraedts J. Severe mental retardation in a patient with tricho-rhinophalangeal syndrome type $\mathrm{I}$ and $8 \mathrm{q}$ deletion. Eur $f$ Pediatr 1990;149:618-20.

${ }^{279}$ Naritomi K, Hirayama K. Partial trisomy of distal $8 \mathrm{q}$ derived from mother with mosaic 8q23.3-24.13 deletion, and relatively mild expression of tricho-rhinophalangeal syndrome I. Hum Genet 1989;82:199-201.

280 Yamamoto Y, Oguro N, Miyao M, Yanagisawa M. Trichorhino-phalangeal syndrome type I with severe mental retardation due to interstitial deletion of 8q23.3-24.13. Am $\mathcal{F}$ Med Genet 1989;32:133-5.

${ }^{81}$ Haan EA, Hull YJ, White S, et al. Tricho-rhino-phalangeal and branchio-oto syndromes in a family with an inherited rearrangement of chromosome 8q. Am $\mathcal{f}$ Med Genet 1989;32:490-4.

VCFS Velo-cardio-facial syndrome

${ }^{282}$ Driscoll DA, Spinner NB, Budarf ML, et al. Deletions and microdeletions of 22q11.2 in velo-cardio-facial syndrome. Am $\mathcal{F}$ Med Genet 1992;44:261-8.

${ }^{283}$ Scambler PJ, Kelly D, Lindsay E, et al. Velo-cardio-facial syndrome associated with chromosome 22 deletions encompassing the DiGeorge locus. Lancet 1992;339: 1138-9.

284 Kelly D, Goldberg R, Wilson D, et al. Confirmation that the velo-cardio-facial syndrome is associated with haploinsufficiency of genes at chromosome 22q11. Am $\mathcal{f}$ Med Genet 1993;45:308-12.

VWS Van der Woude syndrome 1

Bocian M, Walker AP. Lip pits and deletion 1q32-q41. Am f Med Genet 1987;26:437-43.

WAGR see also AN2, WT1 15

${ }_{286}$ Puissant H, Azoulay M, Serre JL, Piet LL, Junien C. Molecular analysis of a reciprocal translocation $\mathrm{t}(5 ; 11)(\mathrm{q} 11 ; \mathrm{p} 13)$ in a WAGR patient. Hum Genet 1988;79:280-2.

WS1 Wardenburg syndrome $1^{137}$

Ishikiriyama S, Tonoki $\mathrm{H}$, Shibuya $\mathrm{Y}$, et al. Wardenburg syndrome type $I$ in a child with a de novo inversion (2)(q35q37.3). Am f Med Genet 1989;33:505-7.

WT1 Wilms's tumour susceptibility ${ }^{15-17}$ 20-23 45-49 52-57 128 168-

XK Kell blood group precursor (McLeod phenotype)

Ho MF, Monaco AP, Blonden LAJ, et al. Fine mapping of the McLeod locus (XK) to a $150-380$-kb region in Xp21. Am f Hum Genet 1992;50:317-30.

ZWS Zellweger syndrome ${ }^{3031}$ 